\title{
Energy Resources of the United States
}




\section{DISCLAIMER}

This report was prepared as an account of work sponsored by an agency of the United States Government. Neither the United States Government nor any agency Thereof, nor any of their employees, makes any warranty, express or implied, or assumes any legal liability or responsibility for the accuracy, completeness, or usefulness of any information, apparatus, product, or process disclosed, or represents that its use would not infringe privately owned rights. Reference herein to any specific commercial product, process, or service by trade name, trademark, manufacturer, or otherwise does not necessarily constitute or imply its endorsement, recommendation, or favoring by the United States Government or any agency thereof. The views and opinions of authors expressed herein do not necessarily state or reflect those of the United States Government or any agency thereof. 


\section{DISCLAIMER}

Portions of this document may be illegible in electronic image products. Images are produced from the best available original document. 


\section{Energy Resources of the United States}

By P. K. Theobald, S. P. Schweinfurth, and D. C. Duncan

GEOLOGICAL SURVEY CIRCULAR 650 


\section{United States Department of the Interior}

ROGERS C. B. MORTON, Secretary

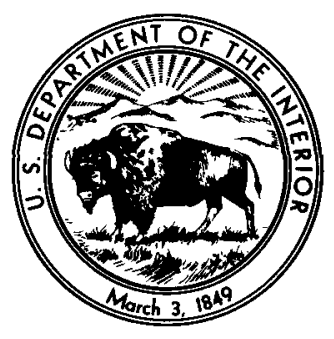

\section{Geological Survey}

V. E. McKelvey, Director 


\section{CONTENTS}

Abstract

Introduction

Coal resources

Sulfur content of coal

Comparison with other recent coal-resource

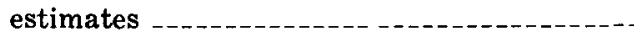

Bituminous coal resources of the Appalachian basin ....................................

Low-sulfur coal resources of the Appalachian basin

Petroleum liquids and natural-gas resources ...-.-

Comparison with other petroleum liquids and natural-gas resource estimates ........ 12

Terminology -

Known deposits ................... 12

Undiscovered deposits .............. 19

Total resources in place ............ 19

Individual estimates _................ 19

Methodology _..._.
Page

1

1

3

4

4

5

5

5

2

12

Ura

Petroleum liquids and natural gas-Con. Comparison with other estimates-Con. Individual estimates-Con. Methodology-Con.

Geologic methods _...... 19

Mathematical methods...._._._. 20 Discussion of individual estimates _._ 20 National Petroleum Council _._-_ 20 U.S. Geological Survey _-_____ 21 M. K. Hubbert _ L. G. Weeks _ C. L. Moore M. A. Elliott and H. R. Linden Potential Gas Committee -...... 22 T. W. Nelson and C. A. Burk ... 22

Uranium resources ................ 23

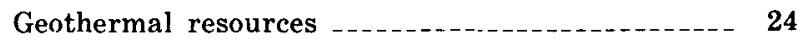

Oil-shale resources

References cited -... 26

\section{ILLUSTRATIONS}

FIgURE 1. Conceptual diagram for the classification of mineral resources

2-12. Scaled diagrams of resources:

2. Coal in the United States

3. Bituminous coal of the Appalachian basin

4. Low-sulfur coal of the Appalachian basin

5. Crude oil and natural-gas liquids in the United States

6. Crude oil and natural-gas liquids in Alaska

7. Crude oil and natural-gas liquids off shore from the United States

8. Crude oil and natural-gas liquids onshore in the conterminous United States ............

9. Natural gas in the United States

10. Natural gas in Alaska

11. Natural gas offshore from the United States

12. Natural gas onshore in the conterminous United States

13-15. Diagrams showing some estimates of original resources of petroleum liquids:

13. United States

14. United States onshore

15. United States off shore

16-18. Diagrams showing some estimates of original resources of natural gas:

16. United States

17. United States onshore

18. United States offshore

19, 20. Scaled diagrams of uranium resources in the United States:

19. Conventional deposits

20. Phosphate rock

21. Diagram of geothermal resources in the United States

22. Scaled diagram of oil-shale resources in the United States 


\title{
Energy Resources of the United States
}

\author{
By P. K. Theobald, S. P. Schweinfurth, and D. C. Duncan
}

\begin{abstract}
Estimates are made of United States resources of coal, petroleum liquids, natural gas, uranium, geothermal energy, and oil from oil shale. The estimates, compiled by specialists of the U.S. Geological Survey, are generally made on geologic projections of favorable rocks and on anticipated frequency of the energy resource in the favorable rocks. Accuracy of the estimates probably ranges from 20 to 50 percent for identifiedrecoverable resources to about an order of magnitude for undiscovered-submarginal resources.

The total coal resource base in the United States is estimated to be about 3,200 billion tons, of which $200-$ 390 billion tons can be considered in the category identified and recoverable. More than 70 percent of current production comes from the Appalachian basin where the resource base, better known than for the United States as a whole, is about 330 billion tons, of which 22 billion tons is identified and recoverable. Coals containing less than 1 percent sulfur are the premium coals. These are abundant in the western coal fields, but in the Appalachian basin the resource base for low-sulfur coal is estimated to be only a little more than 100 billion tons, of which 12 billion tons is identified and recoverable.

Of the many estimates of petroleum liquids and natural-gas resources, those of the U.S. Geological Survey are the largest because, in general, our estimates include the largest proportion of favorable ground for exploration. We estimate the total resource base for petroleum liquids to be about 2,900 billion barrels, of which 52 billion barrels is identified and recoverable. Of the total resource base, some 600 billion barrels is in Alaska or offshore from Alaska, 1,500 billion barrels is offshore from the United States, and 1,300 billion barrels is onshore in the conterminous United States. Identified-recoverable resources of petroleum liquids corresponding to these geographic units are 11,6 , and 36 billion barrels, respectively.

The total natural-gas resource of the United States is estimated to be about 6,600 trillion cubic feet, of which 290 trillion cubic feet is identified and recoverable. In geographic units comparable to those for petroleum liquids, the resource bases are $1,400,3,400$, and 2,900 trillion cubic feet, and the identified-recoverable resources are 31,40 , and 220 trillion cubic feet, respectively.
\end{abstract}

Uranium resources in conventional deposits, where uranium is the major product, are estimated at 1,600 ,000 tons of $\mathrm{U}_{1} \mathrm{O}$, of which 250,000 tons is identified and recoverable. A potential byproduct resource of more than 7 million tons of $\mathrm{U} O$ is estimated for phosphate rock, but none of this resource is recovered under present economic conditions.

The resources of heat in potential geothermal energy sources are poorly known. The total resource base for the United States is certainly greater than $10^{22}$ calories, of which only $2.5 \times 10^{18}$ calories can be considered identified and recoverable at present.

Oil shale is estimated to contain 26 trillion barrels of oil. None of this resource is economic at present, but if prices increase moderately, 160-600 billion barrels of this oil could be shifted into the identified-recoverable category.

\section{INTRODUCTION}

The accompanying diagrams present the U.S. Geological Survey estimates of the United States resources of coal, petroleum liquids, natural gas, uranium, geothermal energy, and oil from oil shale. The estimates have been compiled by a group of specialists familiar with each of the energy sources, each using techniques he considers most useful for estimating his particular energy source. The short text accompanying each diagram outlines the method of estimation or the source of the estimate and defines the characteristics of each estimate. Where appropriate, comparisons with other estimates are also given.

Resources, as used here, include all rocks and minerals (including their contained heat for geothermal sources) potentially usable by man, including currently known and recoverable reserves, undiscovered resources which are estimated geologically or mathematically and which would be recoverable if found, and energy sources (identified and undiscovered) whose exploitation will require more favorable 


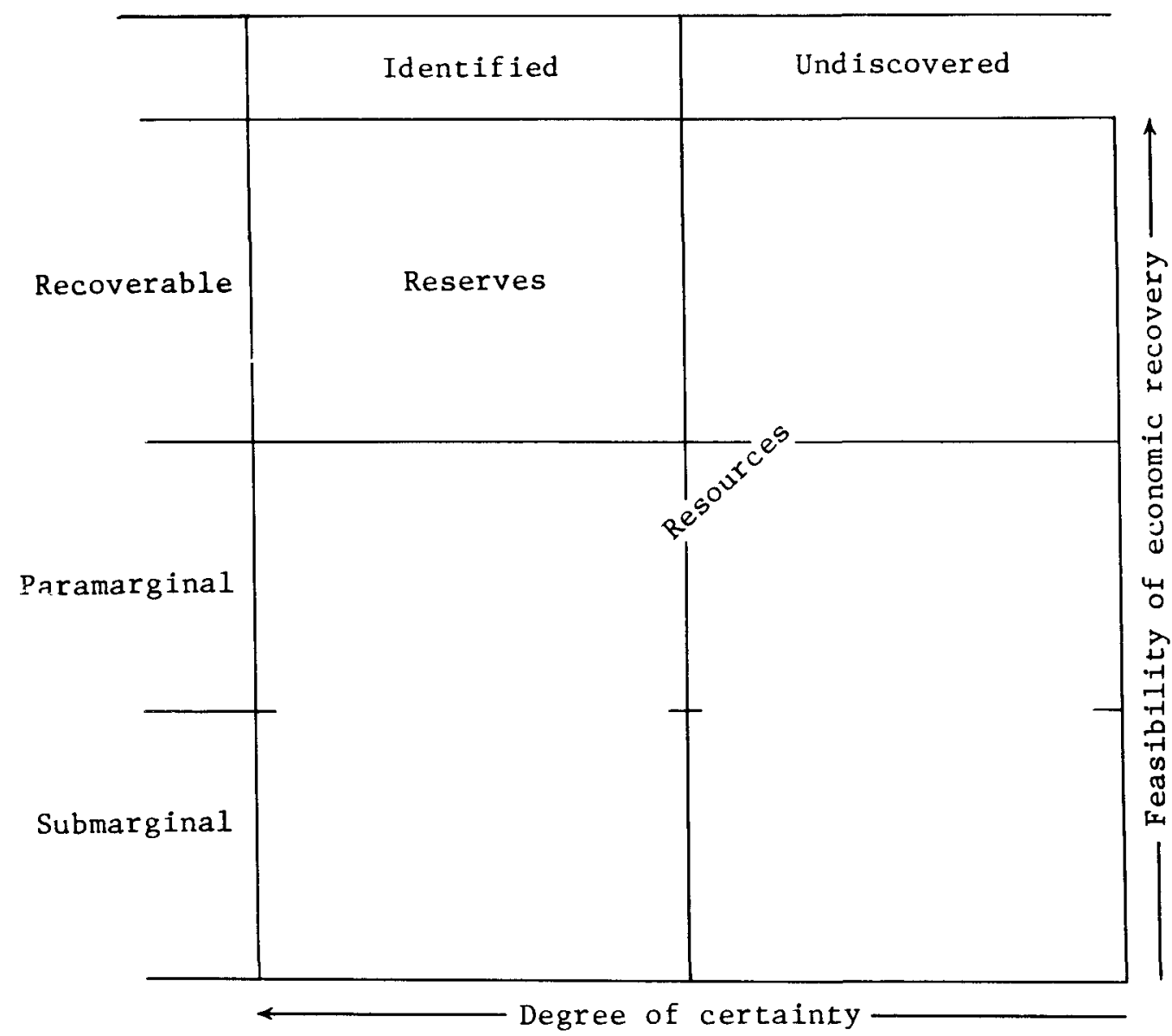

Figure 1.-Conceptual diagram for the classification of mineral resources. From McKelvey (1972).

economic or technologic conditions than those of the present. The diagrams are patterned after the classification of mineral reserves and resources proposed by McKelvey (1972).

The horizontal scale in figure 1 shows degree of certainty, increasing to the left, with a twofold major division, undiscovered to the right and identified to the left. This division has been used in this report. For some energy sources, a subdivision of the undiscovered resources has been added, again based on degree of certainty, to estimate to greater depths (coal) or to distinguish estimates in known districts from those in undiscovered districts (uranium, oil shale).

The vertical scale is feasibility of economic recovery, increasing upward, with a threefold division into submarginal, paramarginal, and recoverable. We have retained the recoverable unit in all our diagrams and have indicated the approximate position of the boundary between paramarginal (defined by McKelvey, 1972, as "recoverable at prices as much as 1.5 times those prevailing now") and submarginal where feasible. Where this latter split cannot be made, the entire field below recoverable is called submarginal. Whether the undiscovered resources may be subdivided according to feasibility of economic recovery depends upon the method of estimation. Where this subdivision cannot be made, we have assumed that the eventual breakdown will be approximately proportional to that for the identified resources.

The various areas of the diagrams presented here have been approximately scaled within each commodity; for example, the area of the block for identified recoverable resources (reserves) for a commodity is proportional to the magnitude of the number in the block relative to the magnitude of the total resource base for 
that commodity. The single exception is for geothermal energy where the proportion of the resource that is identified and recoverable is too small to show without exaggeration. In all diagrams, the figures for the total resource base, that is, the total of all resources in the diagram, are in the units common to that commodity and are for material at the well head or mine portal; that part left in the ground is included with the submarginal resource. No attempt has been made in these estimates to evaluate the efficiency of energy-conversion methods or the efficiency of future extraction technology.

The estimates of identified recoverable resources in the upper left corner of the diagram are within 20-50 percent of the correct value. The estimates of undiscovered submarginal resources in the lower right corner of the diagram reflect only an order of magnitude. To be realized, these less known resources, which constitute the bulk of the resource base, will require great advances in the technologies of both search and extraction. Similarly, the submarginal identified resources require advances in extraction technology before utilzation is feasible, whereas the undiscovered recoverable resources require a continuing effort in both exploration and exploration research as well as economic incentive.

\section{COAL RESOURCES}

Coal resources are classified in two broad categories: identified resources and undiscovered resources (fig. 2). Short tons of coal are the units for coal resource estimation. Identified resources include coal beds that have been mapped and tonnage estimates prepared on a thickness and general-quality basis. Such estimates include, in order of decreasing reliability, measured and indicated reserves as well as inferred conservative extensions of individual coal beds.

Recoverable coal is identified and separated from submarginal coal with the field of identified resources. Two estimates of recoverable coal have been made, dependent upon the thickness of the coal beds. With a cutoff at 42 inches in thickness for bituminous coal and anthracite and at 10 feet for subbituminous coal and lignite, approximately 200 billion short tons can be recovered within 1,000 feet of the sur-

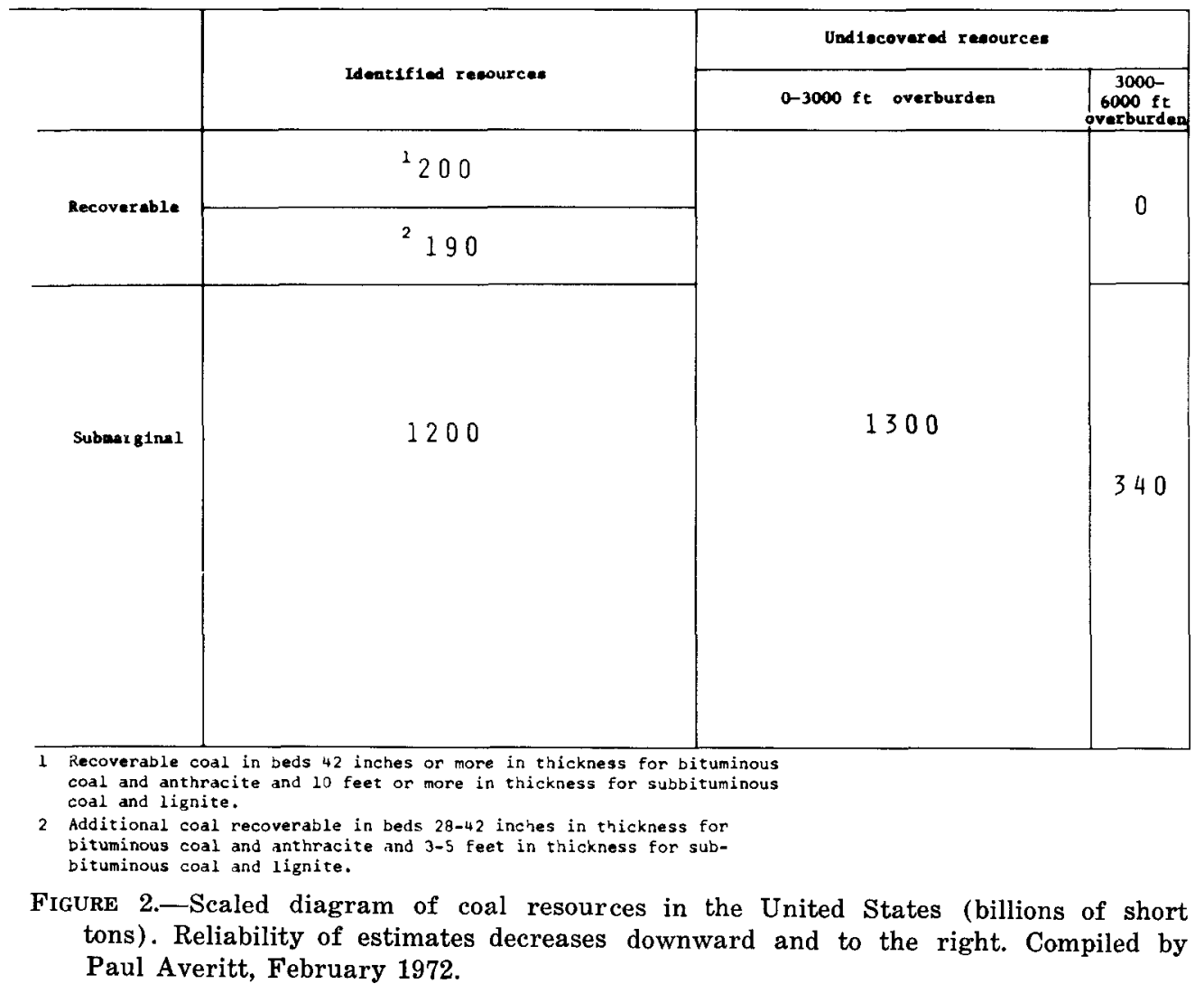


face at a recovery factor of 50 percent. With a cutoff at 28 inches in thickness for bituminous coal and anthracite and at 5 feet for subbituminous coal and lignite, an additional 190 billion short tons is recoverable within 1,000 feet of the surface at a recovery factor of $\mathbf{5 0}$ percent. The total recoverable coal at a 28inch cutoff is, therefore, 390 billion tons. These two estimates of recoverable coal-200 billion short tons and 390 billion short tons-appear in different editions of "United States Energy, a Summary Review" (U.S. Dept. Interior, 1972, p. 29). It is assumed that coal that can be mined at depths greater than 1,000 feet approximately compensates for coal shallower than 1,000 feet that cannot be mined for geologic or land-use reasons.

The submarginal coal estimate includes the thicker coal left in the ground on first mining and thinner coal beds to a cutoff at 14 inches thickness for bituminous coal and anthracite and at 30 inches for subbituminous coal and lignite. This estimate includes coal to a depth of 6,000 feet below the surface.

Undiscovered coal resources include coal deposits that have not been mapped or sampled in detail within the known coal fields. (All the coal fields are known in some degree.) These resources are estimated on expected volumes of favorable rocks and expected coal frequency within these rocks in unmapped or unexplored areas and in basinward projections from the outcrop.

\section{SULFUR CONTENT OF COAL}

In a study of analytical data on coal, DeCarlo, Sheridan, and Murphy (1966, p. 19) concluded that the average sulfur content of the coal in the identified remaining resources of 1,600 billion tons is as shown below.

As shown in the table, subbituminous coal and lignite are conspicuously low in sulfur. The large concentration of coals of these ranks in the Rocky Mountain and northern Great Plains provinces, about 54 percent of total identified United States resources, is responsible for the substantially large amount of low-sulfur coal in the United States as a whole.

However, production of coal is concentrated in the bituminous coal fields of the eastern
Sulfur content of United States coal according to rank

[Modifed from DeCarlo, Sheridan, and Murphy, 1966]

\begin{tabular}{|c|c|c|c|}
\hline \multirow[b]{2}{*}{ Kank } & \multicolumn{3}{|c|}{ Percentage of total resources } \\
\hline & $\begin{array}{r}\text { Low sulfur } \\
0-1 \% 0\end{array}$ & $\begin{array}{c}\text { Medium sulfur } \\
1.1-3 \%\end{array}$ & $\begin{array}{c}\text { High sulfur } \\
>\mathbf{>} \%\end{array}$ \\
\hline Anthracite & 97.1 & 2.9 & - \\
\hline Bituminous coal & 29.8 & 26.8 & 43.4 \\
\hline Subbituminons coal & 99.6 & .4 & 一 \\
\hline Lignite & 90.7 & 9.3 & - - \\
\hline All ranks & 65.0 & 15.0 & 20.0 \\
\hline
\end{tabular}

United States (more than 70 percent of the production in 1969); this coal, as the above table shows, contains substantially more sulfur than the national average. In these areas much additional low-sulfur coal in individual beds and parts of beds can be identified by additional geologic study and exploration. This has been done with some success, as will be noted under the discussion of low-sulfur coal in the Appalachian basin.

\section{COMPARISON WITH OTHER RECENT COAL- RESOURCE ESTIMATES}

Estimates of the coal resources of the United States appear in a variety of publications; two of the more widely used are U.S. Bureau of Mines (1971) and Hubbert (1969). These published estimates are all derived from Averitt (1969), although the figures themselves are sometimes manipulated to fit the context in which they are used. Apparent contradictions among the various figures usually result from differences in the application of recovery factors, from a variety of assumptions used to estimate ultimate conversion to energy, or from restriction of the estimate to particular reliability or quality criteria.

A Bureau of Mines report entitled, "United States Coal Resources and Production-Interim Report, June 1971," deals only with resources in the "identified" category. With minor changes, it draws on the same U.S. Geological Survey and State survey source material used by Averitt (1969).

Hubbert (1969) based his mathematical analysis on both "identified" and "total" (identified plus undiscovered) coal resources. The figure of $1,486 \times 10^{9}$ metric tons that appears in both fig- 
ures 8.24 and 8.26 of that article is the total resource base from our figure $2,3,200 \times 10^{\prime \prime}$ short tons, reduced by a recovery factor of 50 percent and converted to metric units.

\section{BITUMINOUS COAL RESOURCES OF THE APPA- LACHIAN BASIN}

The units, definitions, and means of estimation for figure 3 are the same as those for the United States coal estimate (fig. 2), but have been restricted to the single classification of coal in the one major coal-producing region. The Appalachian basin is defined here as the narrow continuous coal-bearing region extending along the Appalachian Mountains from northern Alabama to western Pennsylvania.

This single basin has been selected for discussion because it provides more than 70 percent of the current coal production and because it contains a smaller proportion of low-sulfur coals (fig. 4) than do the western coal basins.

\section{LOW-SULFUR COAL RESOURCES OF THE APPA- I.ACHIAN BASIN}

Low-surful coals (generally less than 1 percent sulfur) of the Appalachian basin (fig. 4) are less abundant and more in demand than are coals of other qualities or in other locations. This is the premium coal, commanding a higher price for metallurgical use, domestic heating, electric generation, and export.

The estimates of low-sulfur coal presented here are based on the extrapolation of the proportion of low-sulfur coals to the region as a whole from the recent study of selected areas that have received comprehensive study by the U.S. Bureau of Mines (DeCarlo and others, 1966). The units and boundaries of the diagram are the same as for the preceding diagrams of coal resources, except for the average percentage of recovery, which, for this higher priced coal, is closer to 60 percent than to the 50 percent previously used.

The low-sulfur coal estimates were compiled by $K$. J. Englund, mainly from the data of Averitt (1969) and DeCarlo, Sheridan, and Murphy (1966).

\section{PETROLEUM LIQUIDS AND NATURAL-GAS RESOURCES}

The quantities of oil and natural-gas liquids (NGL) in figures 5-8 are uniformly reported in barrels of 42 standard U.S. gallons, whereas

\begin{tabular}{c|c|c|}
\hline & Ident 1f 1ed resources & $\begin{array}{c}\text { Und Iscovered } \\
\text { resources }\end{array}$ \\
\hline Recoverable & 22 & \\
\hline Submarginal & 240 & 70 \\
& & \\
& & \\
\hline
\end{tabular}

Ficure 3.-Scaled diagram of bituminous coal resources of the Appalachian basin (billions of short tons). A part of the coal resources of the United States (fig. 2). Reliability of estimates decreases downward and to the right. Compiled by Paul Averitt, February 1972. 


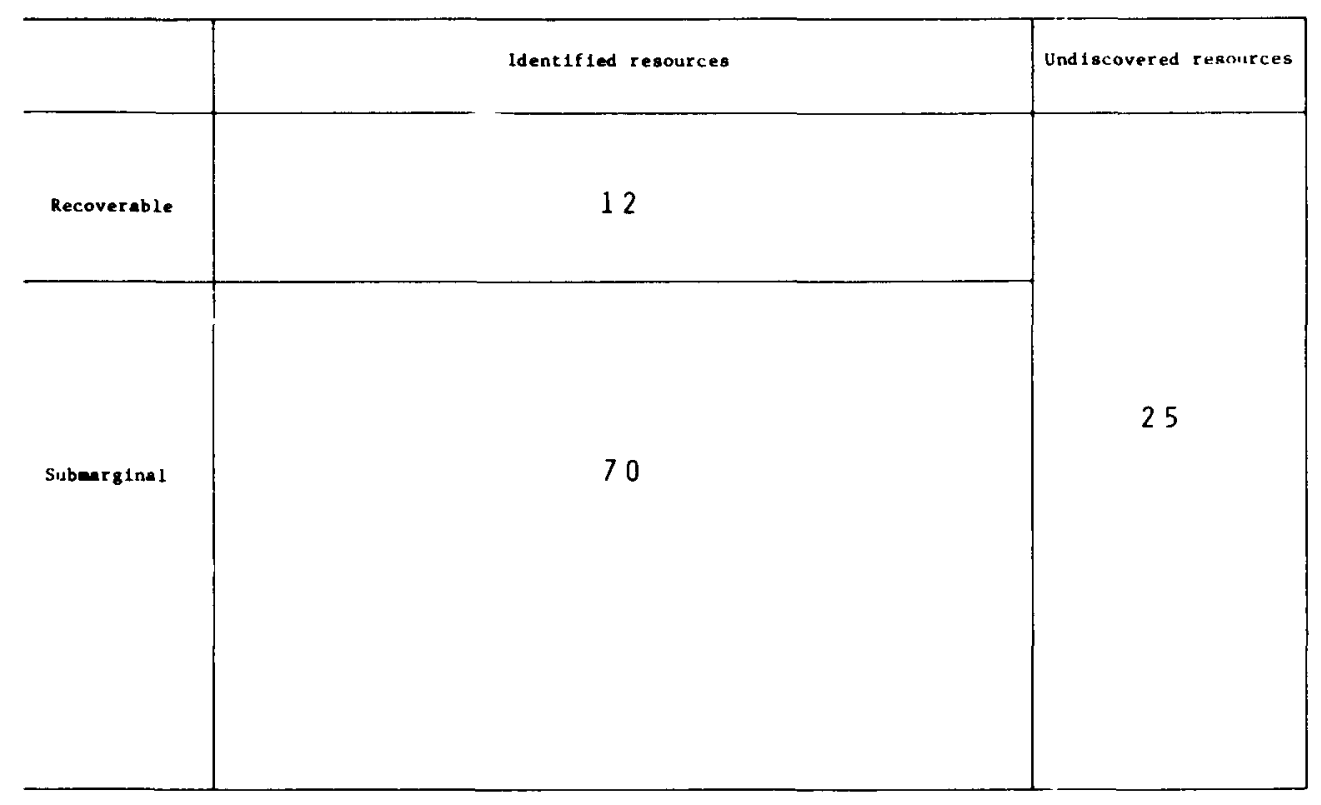

Figure 4.--Scaled diagram of low-sulfur coal resources of the Appalachian basin (billions of short tons). A part of the bituminous coal resources of the Appalachian basin (fig. 3) and a part of the coal resources of the United States (fig. 2). Reliability of estimates decreases downward and to the right. Compiled by K. J. Englund, February 1972.

the quantities of natural gas are reported in cubic feet at a sea-level pressure of 14.73 pounds per square inch at $60^{\circ} \mathrm{F}$.

The quantities of petroleum and natural-gas resources shown in the various categories of figures 5-8 and 9-12 were derived from annual reports of the American Petroleum Institute (API) and the American Gas Association (AGA) and estimates prepared by the U.S. Geological Survey (USGS). The quantities reported under identified recoverable resources in figures 5-8 are the sums of estimates of proved reserves and indicated additional reserves of crude oil published by API plus estimates of proved reserves of NGL published by AGA (Am. Gas Assoc. and others, 1971). (AGA does not estimate indicated additional reserves for the NGL.) The quantities reported under identified recoverable resources in figures 9-12 are estimates of proved reserves of natural gas published by AGA. These estimates assume recovery factors of 35 percent for oil and 80 percent for NGL and for gas.

The API and AGA published estimates of identified resources of petroleum liquids and natural gas are the only ones available for the United States. These estimates are prepared annually by local committees made up of petroleum and natural-gas specialists from both private industry and State governments. These estimates are made on a field-by-field basis and are then agglomerated into a single report giving reserves by States.

Identified submarginal resources reported in figures 5-12 are estimates of quantities of petroleum or natural gas that cannot be recovered from known fields under current technologic and (or) economic conditions. The quantities shown in this category in figures 5-8 are for crude oil only and were derived by subtracting cumulative production, proved reserves, and indicated additional reserves from the API estimate of original oil-in-place. As there is no published estimate of original NGL-in-place and as the NGL recovery factor is approximately 80 percent of NGL-in-place, no attempt was made to calculate a quantity of NGL for the identified submarginal category.

The case of natural gas, in this respect, is similar to that of NGL. However, as the identi- 


\begin{tabular}{|c|c|c|}
\hline & $\begin{array}{c}\text { dent 1fied } \\
\text { resources }\end{array}$ & Und 1ocovered resources \\
\hline Recoverable & 52 & 450 \\
\hline & & 2100 \\
\hline & & \\
\hline
\end{tabular}

Figure 5.-Scaled diagram of crude oil and natural-gas liquids in the United States (including the continental margin to 2,500-m water depth) as of Dec. 31,1970 (billions of barrels). Reliability of estimates decreases downward and to the right. Compiled by S. P. Schweinfurth.

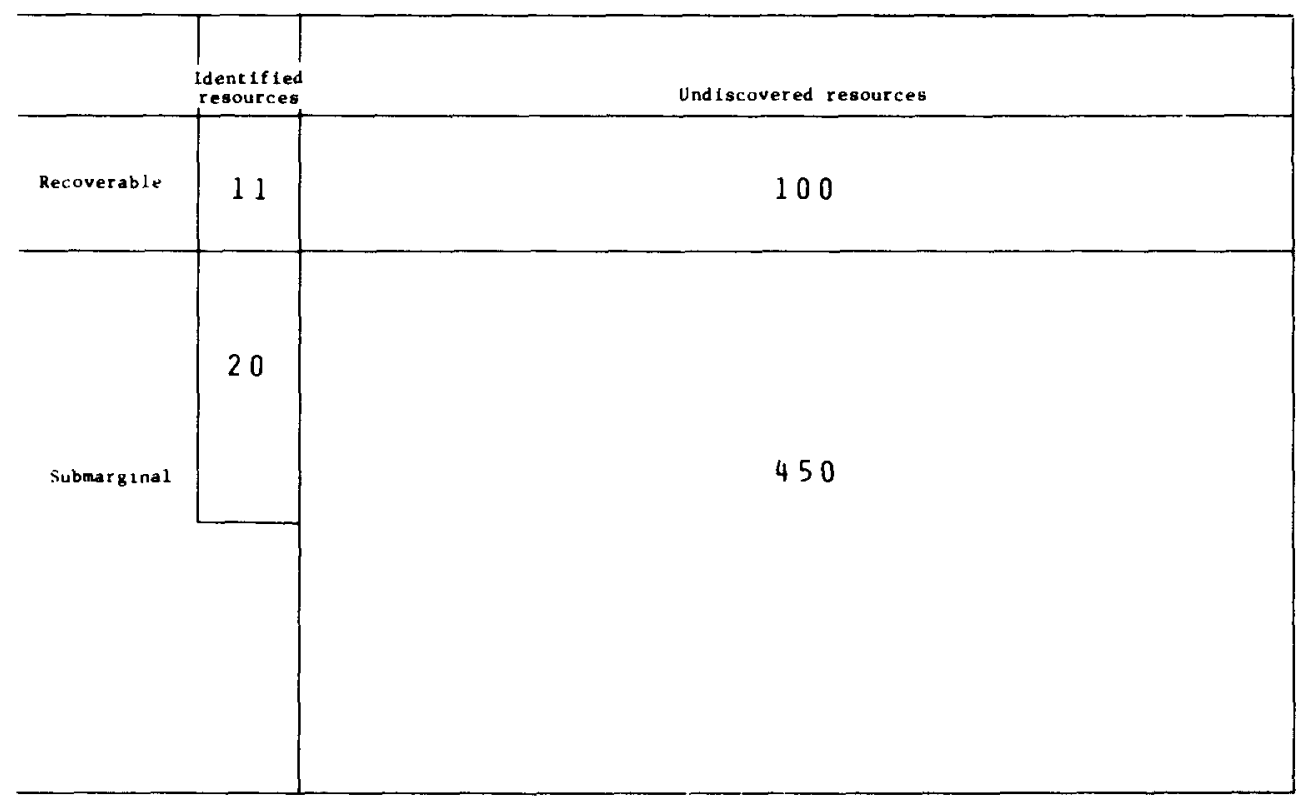

Figure 6.-Scaled diagram of crude oil and natural-gas liquids in Alaska (onshore and continental margin to $2,500-\mathrm{m}$ water depth) as of Dec. 31,1970 (billions of barrels) Included in resources of figure 5 . Reliability of estimates decreases downward and to the right. Compiled by S. P. Schweinfurth. 


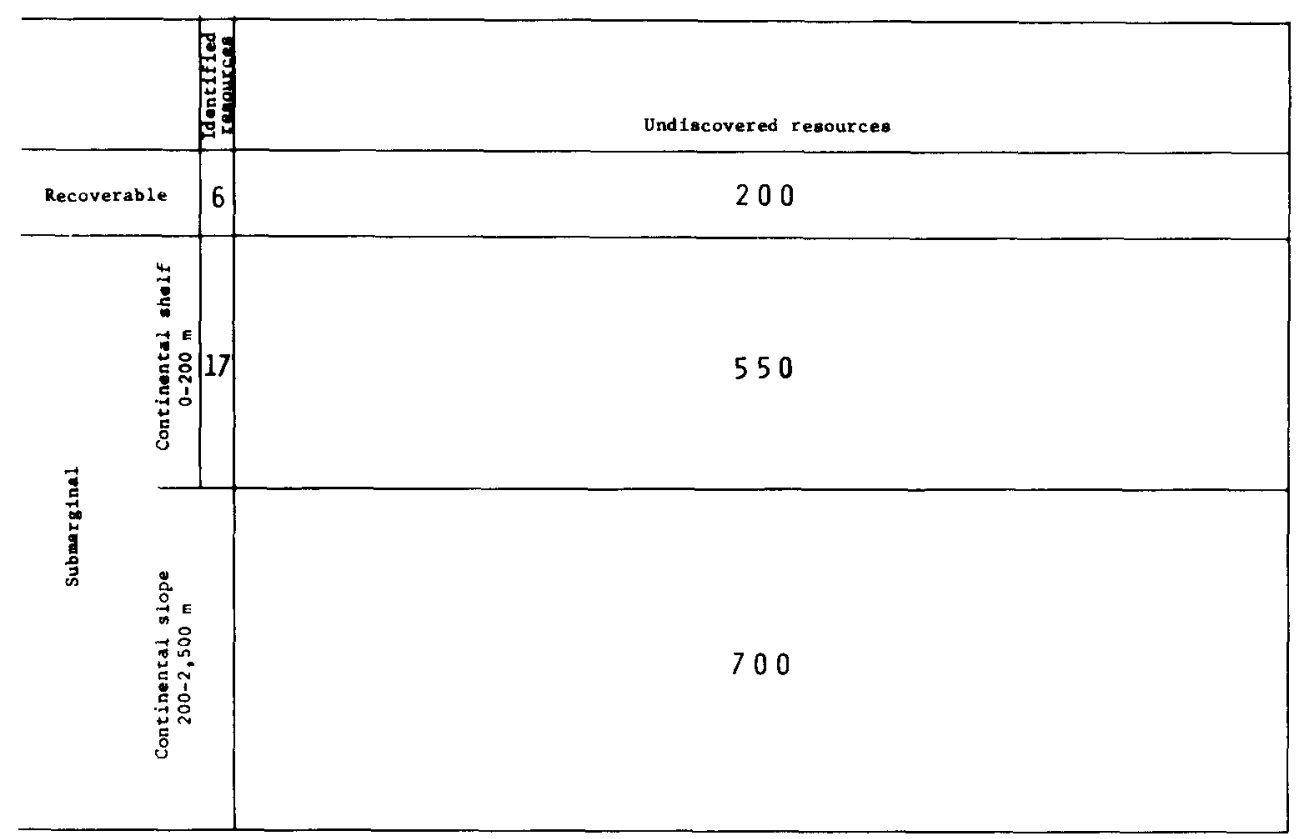

FIgURE 7.-Scaled diagram of crude oil and natural-gas liquids offshore from the United States (conterminous United States and Alaska to 2,500-m water depth) as of Dec. 31, 1970 (billions of barrels). Included in resources of figure 5. Reliability of estimates decreases downward and to the right. Compiled by S. P. Schweinfurth.

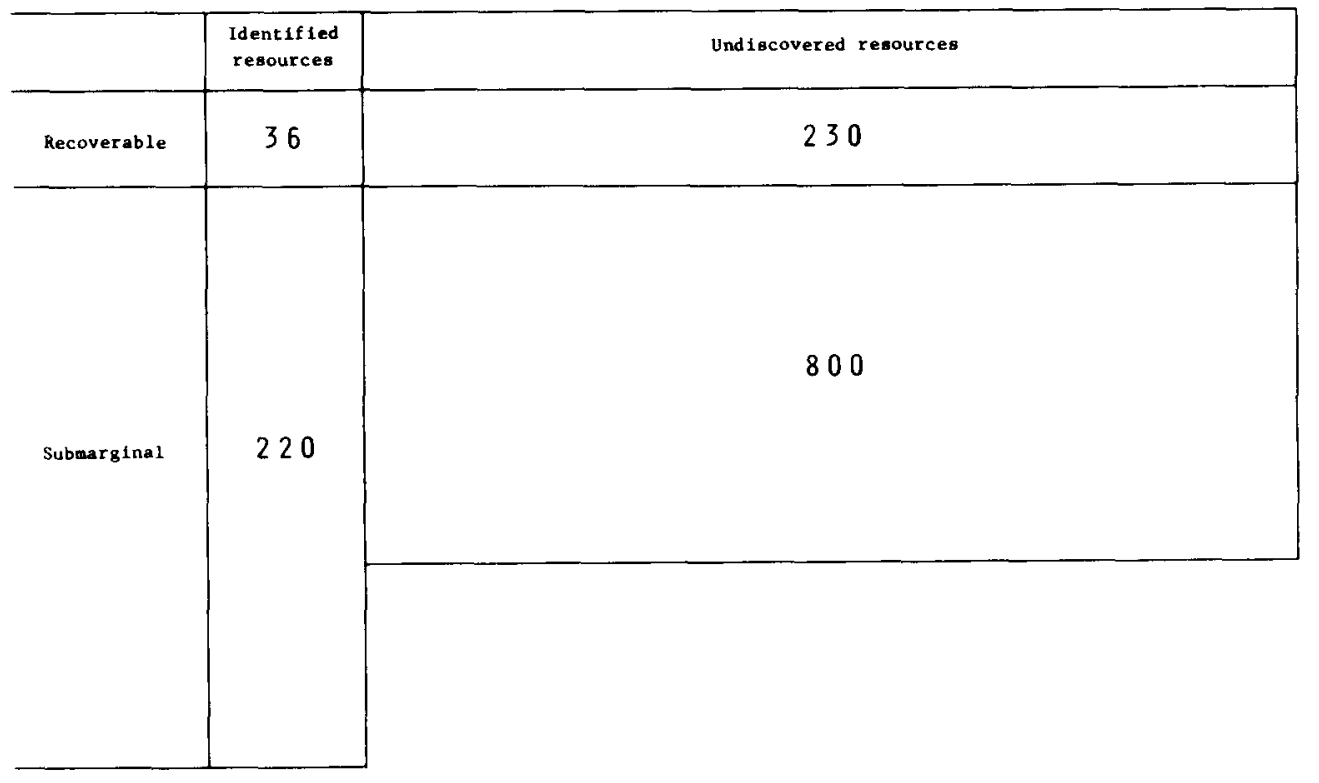

FIGURe 8.-Scaled diagram of crude oil and natural-gas liquids onshore in the conterminous United States as of Dec. 31, 1970 (billions of barrels). Included in resources of figure 5. Reliability of estimates decreases downward and to the right. Compiled by S. P. Schweinfurth. 


\begin{tabular}{|c|c|c|}
\hline & $\begin{array}{c}\text { Idont ified } \\
\text { resources }\end{array}$ & Und1ecovered resources \\
\hline Recoverable & 290 & 2100 \\
\hline & 170 & 4000 \\
\hline
\end{tabular}

FIGURE 9.-Scaled diagram of natural gas resources in the United States (includes continental margin to 2,500-m water depth) as of Dec. 31,1970 (trillions of cubic feet). Reliability of estimates decreases downward and to the right. Compiled by $S$. P. Schweinfurth.

\begin{tabular}{|c|c|c|}
\hline & $\begin{array}{c}\text { Ldent 1fied } \\
\text { resources }\end{array}$ & Und locovered resources \\
\hline Recoverable & 31 & 480 \\
\hline & 8 & \\
\hline & & 860 \\
\hline
\end{tabular}

Figure 10.-Scaled diagram of natural gas resources in Alaska (onshore and continental margin to 2,500-m water depth) as of Dec. 31, 1970 (trillions of cubic feet). Included in resources of figure 9 . Reliability of estimates decreases downward and to the right. Compiled by S. P. Schweinfurth. 


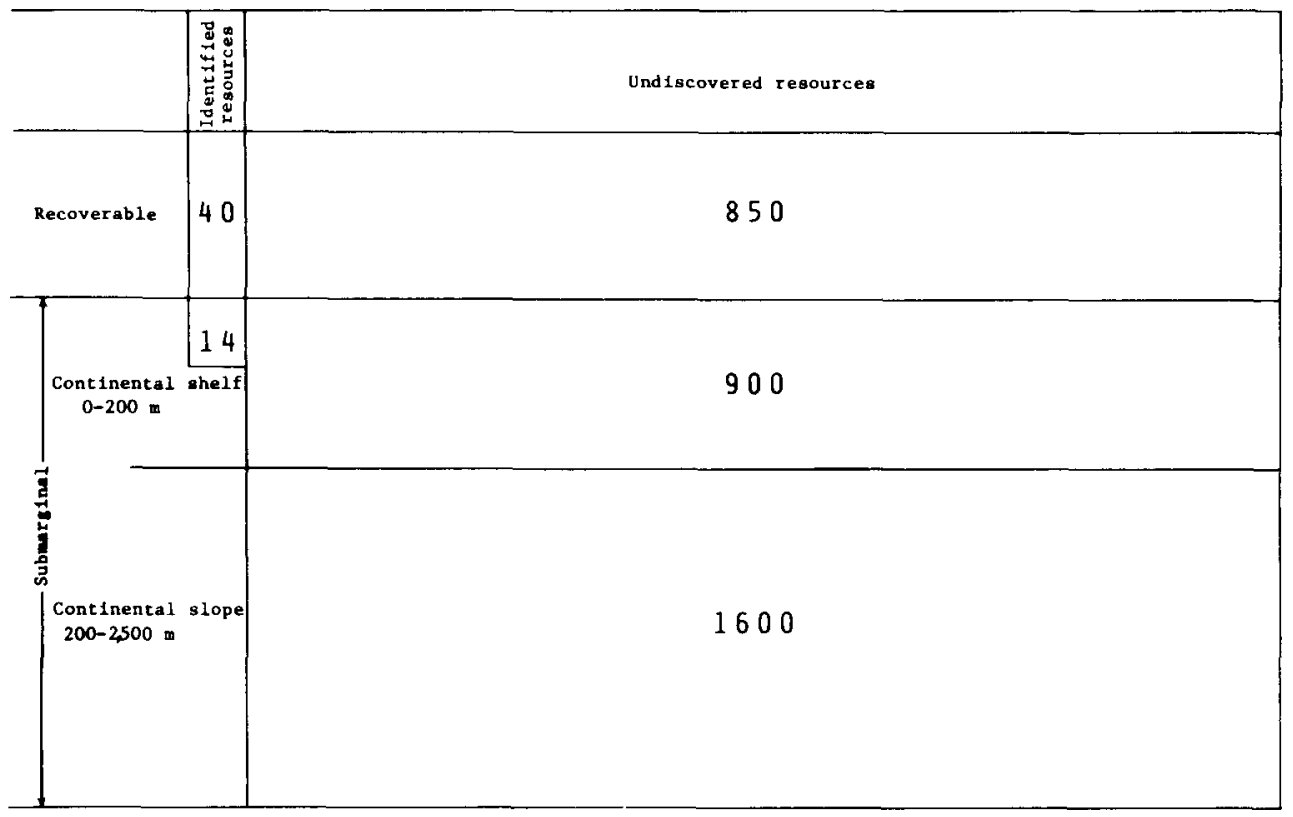

FIGURE 11.-Scaled diagram of natural gas resources offshore from the United States (conterminous United States and Alaska to 2,500-m water depth) as of Dec. 31, 1970 (trillions of cubic feet). Included in resources of figure 9. Reliability of estimates decreases downward and to the right. Compiled by S. P. Schweinfurth.

\begin{tabular}{|c|c|c|}
\hline & $\begin{array}{c}\text { Identified } \\
\text { resources }\end{array}$ & Und 1scovered resources \\
\hline Recoverable & 220 & 1000 \\
\hline & 150 & 1500 \\
\hline & & \\
\hline
\end{tabular}

Figure 12.-Scaled diagram of natural gas resources onshore in the conterminous United States as of Dec. 31, 1970 (trillions of cubic feet). Included in resources of figure 9. Reliability of estimates decreases downward and to the right. Compiled by S. P. Schweinfurth. 
fied quantity of proved reserves and cumulative production of natural gas is so large, it was felt that it would be worthwhile to include an estimate of identified submarginal gas resource, some of it might, one day, be recovered by application of a supplementary or advanced recovery technique. The quantities shown were calculated by applying a recovery factor of 80 percent to the estimates of proved reserves and cumulative production reported by AGA.

Undoubtedly, some part of the quantities reported of identified submarginal liquids and gas could become recoverable with an increase in well-head price or equivalent advances in technology, and, therefore, could now be called paramarginal. The data to make such a breakdown meaningful, however, are not available.

The terms used by API and AGA are defined as follows:

Proved reserves of crude oil are defined as the estimated quantities of crude oil which geological and engineering data demonstrate with reasonable certainty to be recoverable from know reservoirs under existing economic and operating conditions.

Proved reserves include identified crude oil which can be produced through application of fluid injection or other recovery techniques.

Indicated additional reserves of crude oil are certain quantities of crude oil that may be recovered from known reservoirs expected to respond to secondary-recovery techniques when installed.

Original oil-in-place is the estimated number of barrels of crude oil in known reservoirs prior to any production. It includes past production and recoverable and nonrecoverable oil.

Proved reserves of natural gas and NGL have the same definitions as crude oil.

The quantities of undiscovered resources reported in figures 5-12 are estimates, considerably rounded, that were prepared by the USGS (Hendricks, 1965; Hendricks and Schweinfurth, unpub. data, 1966 ; McKelvey and others, 1969 ; Schweinfurth, unpub. data, 1971).

Undiscovered resources of crude oil were estimated first by the USGS by extrapolating the results of past exploration drilling to the remaining unexplored but favorable rocks of the United States. Allowance was made for the expected decline in reward (oil found per well drilled) for future drilling. (Details of the USGS estimating method are discussed in the following section, along with some additional estimates of undiscovered petroleum resources.) The undiscovered resources of natural gas and NGL were calculated by applying a gas-oil ratio to the crude-oil estimate and then by applying a NGL-gas ratio to the calculated quantity of natural gas.

This method was applied to the total favorable rocks of the United States to a drilling depth of 20,000 feet. The resultant estimate was then broken down into separate figures for the conterminous United States, Alaska, and their respective continental margins to water depths of 2,500-m $(8,250 \mathrm{ft})$.

Estimates of undiscovered resources of crude oil and NGL are reported together as petroleum liquids in figures 5-8, and estimates of natural gas are given separately in figures 9-12.

Undiscovered resources are separated into recoverable and submarginal categories, Recoverable undiscovered resources are quantities of petroleum liquids and natural gas that may be found using existing exploration technology and produced under approximately current conditions of economics and technology.

The quantities of liquids and gas reported in the submarginal undiscovered category are those quantities estimated to be present but that cannot now be produced if found, or that might never be found because of small size or remote location. The actual quantities reported were calculated by applying first a discovery factor (it is assumed that five-eighths of the resource in the ground will be found) and then a recovery factor to the estimated total undiscovered liquids-or gas-in-place. The estimates for the United States continental slope (200$2,500 \mathrm{~m}$ ), however, are entirely in the submarginal category because there has been almost no attempt to explore for, and no attempt to produce, petroleum in waters deeper than 200 $m$. As a result all the quantities reported in the undiscovered submarginal resources of figures 5-7 and 9-11 are proportionately much larger in relation to the identified submarginal resources than the recoverable undiscovered resources are to the identified recoverable resources in the same figures. 
As for identified submarginal petroleum liquids and natural-gas resources, part of the undiscovered submarginal resources could be recovered when found. Therefore, this part could be considered to be paramarginal if real prices were to increase and if technology were to advance beyond today's levels, but there is no way at this time to tell what the amounts of the resources might be.

\section{COMPARISON WITH OTHER PETROLEUM LIQUIDS AND NATURAL-GAS RESOURCE ESTIMATES}

The estimates included were selected on the basis of timeliness and broadness of coverage. No one of them, however, is directly comparable with any of the others because each was made by a different method or methods (although some are quite similar in method) and (or) for a larger or smaller part of the total ground favorable for petroleum.

The authors of the estimates chosen are listed here; their estimates will be discussed in some detail later. The authors are: (a) Miller and others (1970); (b) U.S. Geological Survey: Hendricks and Schweinfurth (unpub. data, 1966); McKelvey and others (1969); Schwienfurth (unpub. data, 1971) ; (c) Hubbert (1969); (d) Weeks (1958, 1959); (e) Moore (1970); (f) Elliott and Linden (1968); (g) Potential Gas Committee (PGC) (Colorado School Mines Found., Potential Gas Agency, 1971); and (h) Nelson and Burk (1966).

Estimates of these resources have been fitted as well as possible into the diagram of McKelvey (1972) for purposes of comparison with each other. Figures 13-18 summarize the results. For detailed terminology, however, it was deemed advisable to use the terminology of the U.S. petroleum industry, which describes categories of known reserves and potential future reserves, because industry groups (API, AGA, PGC, NPC) have produced the most detailed definitions and work on this subject. It was relatively easy to relate, at least generally, the terminology of the industry to McKelvey's terminology.

\section{TERMINOLOGY}

KNOWN DEPOSITS

Known resources, cumulative (past) production, proved reserves, and indicated additional reserves are terms defined and used by the API in its annual report of reserves of crude oil in the United States (see, for example, Am. Gas Assoc. and others, 1971). The API also reports on discovered total original oil-in-place. These terms refer to crude oil, and crude oil only, that has been discovered as of a certain date (always the end of December of the given year). Cumulative production, proved reserves, and indicated additional reserves refer to quantities that either have been or could be produced under current economic and technologic conditions. The difference between these quantities and discovered total original oil-in-place gives McKelvey's known paramarginal and submarginal resources (nonrecoverable under current conditions) of crude oil as of the same reporting date.

The API also reports proved reserves of NGL but does not report either cumulative production, or indicated additional reserves, or total original NGL-in-place for the gas liquids. Apparently there is yet no reliable statistical series on either total original NGL-in-place or cumulative production of NGL, and the category indicated additional reserves is not applicable to gas liquids because they are not generally amenable to secondary-recovery methods, whereas crude oil is. Therefore, a quantity for past production of NGL was estimated by the USGS but no estimate of known para-and submarginal resources of NGL was calculated.

Known quantities of natural-gas reserves are reported as proved reserves by the AGA (see Am. Gas Assoc. and others, 1971) as of the end of a given year. Cumulative (past) production is also reported, whereas discovered total original gas-in-place is not. The report of cumulative production (gas) is at best an estimate, because for many years gas produced with oil was flared (burned), and no reliable production records were kept. Indicated additional reserves are not reported by the AGA for gas because it is not very amenable to secondary recovery and because initial recovery is high (approximately 80 percent of gas-in-place).

A quantity for known para- and submarginal resources of gas was calculated by the USGS, however, because the amount is large and because additional or secondary recovery might one day become feasible. 


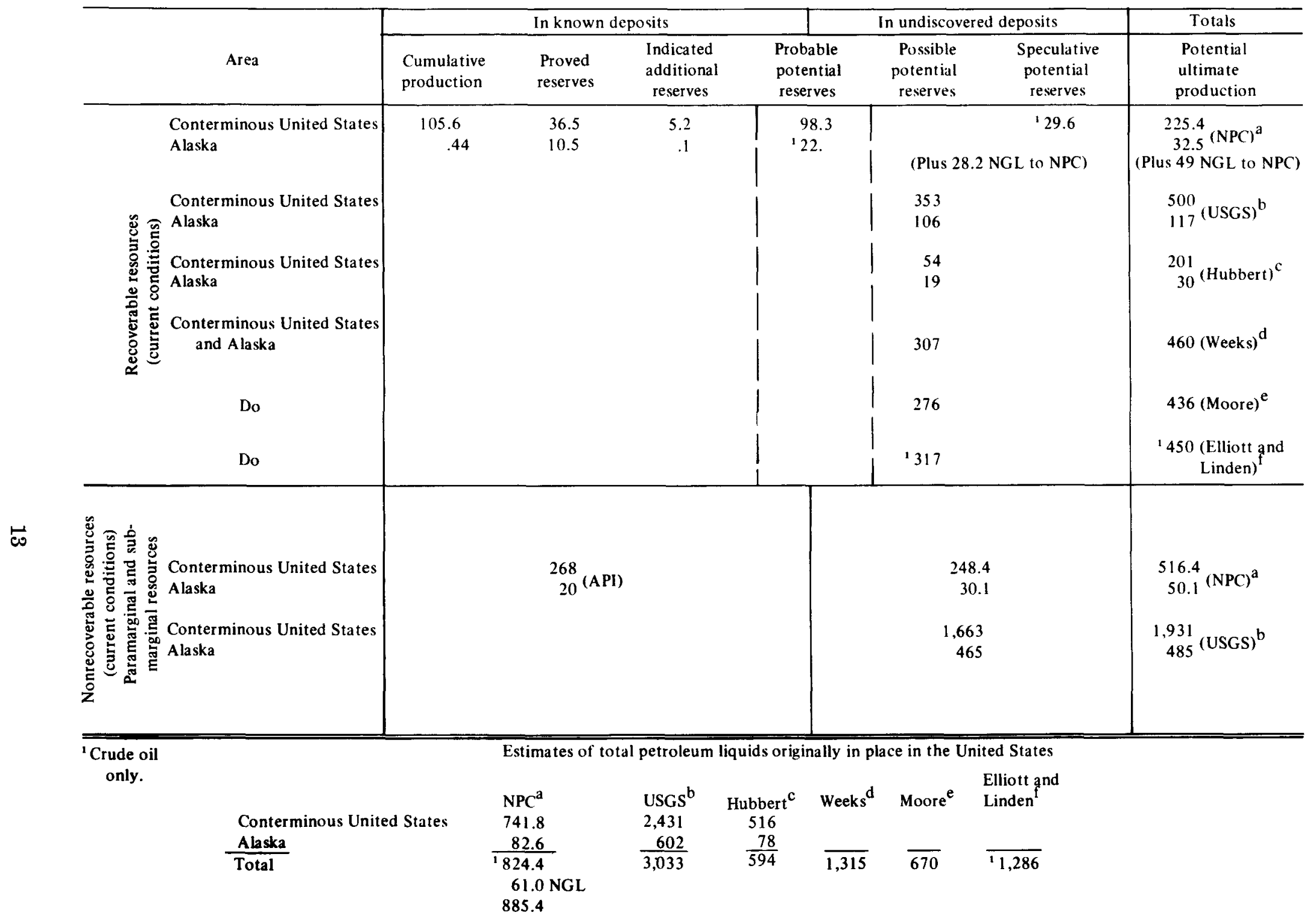

Frgure 13.- Some estimates of United States original resources of petroleum liquids (crude oil and natural-gas liquids in billions of barrels). Data to Dec. 31, 1970. The values reported in this figure are not rounded but are simply arithmetic calculations. The accuracy of the figures is largely unevaluated, and the number of significant figures is not indicated in the numbers. Lettered footnote symbols are explained in the section "Discussion of Individual Estimates." 


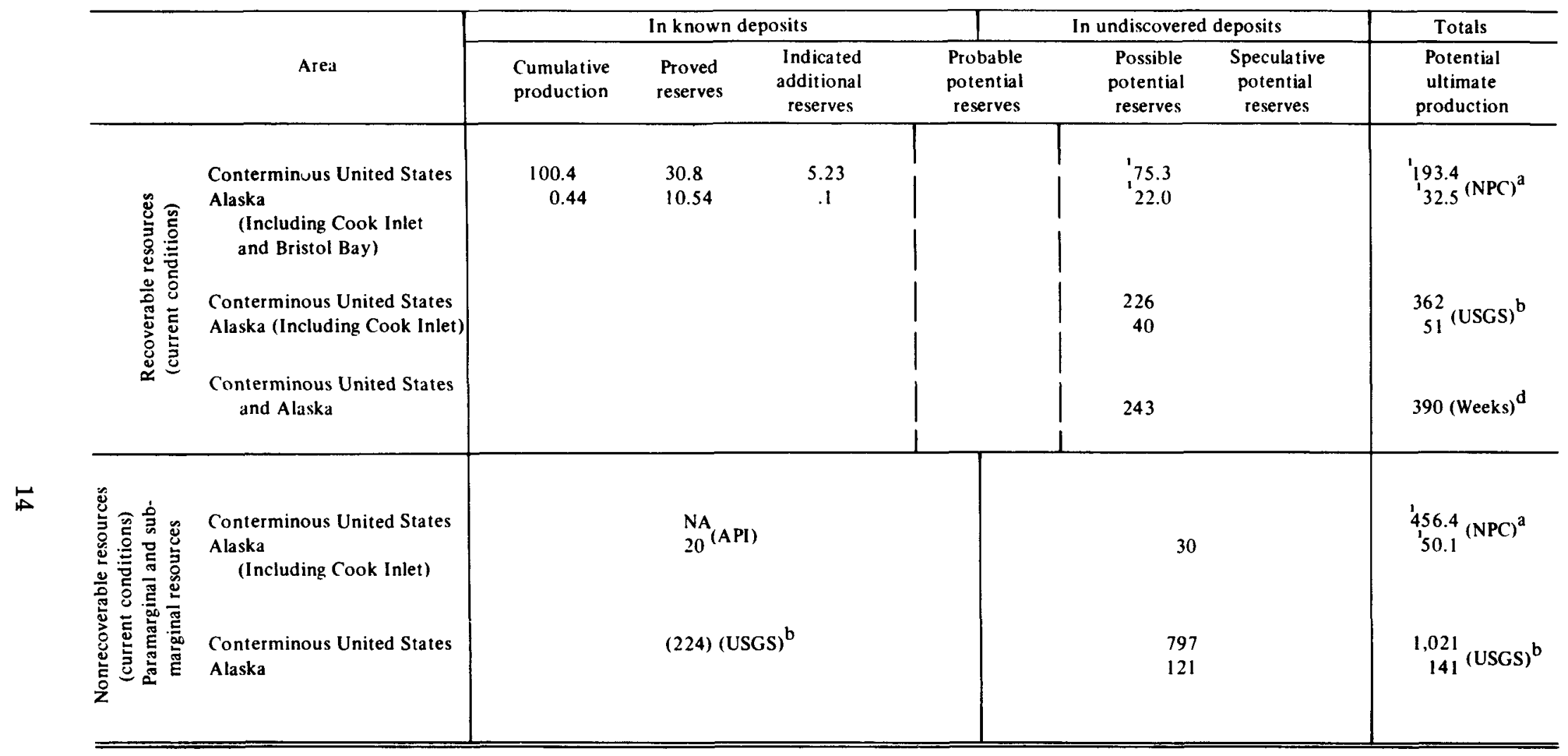

Crude oil only.

Estimates of total petroleum liquids originally in place in the land areas of the United States

\begin{tabular}{|c|c|c|c|}
\hline & $N P C^{a}$ & USGS $^{\mathrm{b}}$. & Weeks ${ }^{d}$ \\
\hline $\begin{array}{l}\text { Conterminous United States } \\
\text { Alaska }\end{array}$ & $\begin{array}{r}649.8 \\
82.6\end{array}$ & $\begin{array}{r}1,383 \\
192\end{array}$ & 1,114 \\
\hline Total & 732.4 & 1.575 & 1,114 \\
\hline
\end{tabular}

Figure 14.-Some estimates of United States original onshore resources of petroleum liquids (crude oil and natural-gas liquids in billions of barrels). Data to Dec. 31, 1970. The values reported in this figure are not rounded but are simply arithmetic calculations. The accuracy of the figures is largely unevaluated, and the number of significant figures is not indicated in the numbers. NA, not available. Lettered footnote symbols are explained in the section "Discussion of Individual Estimates." 


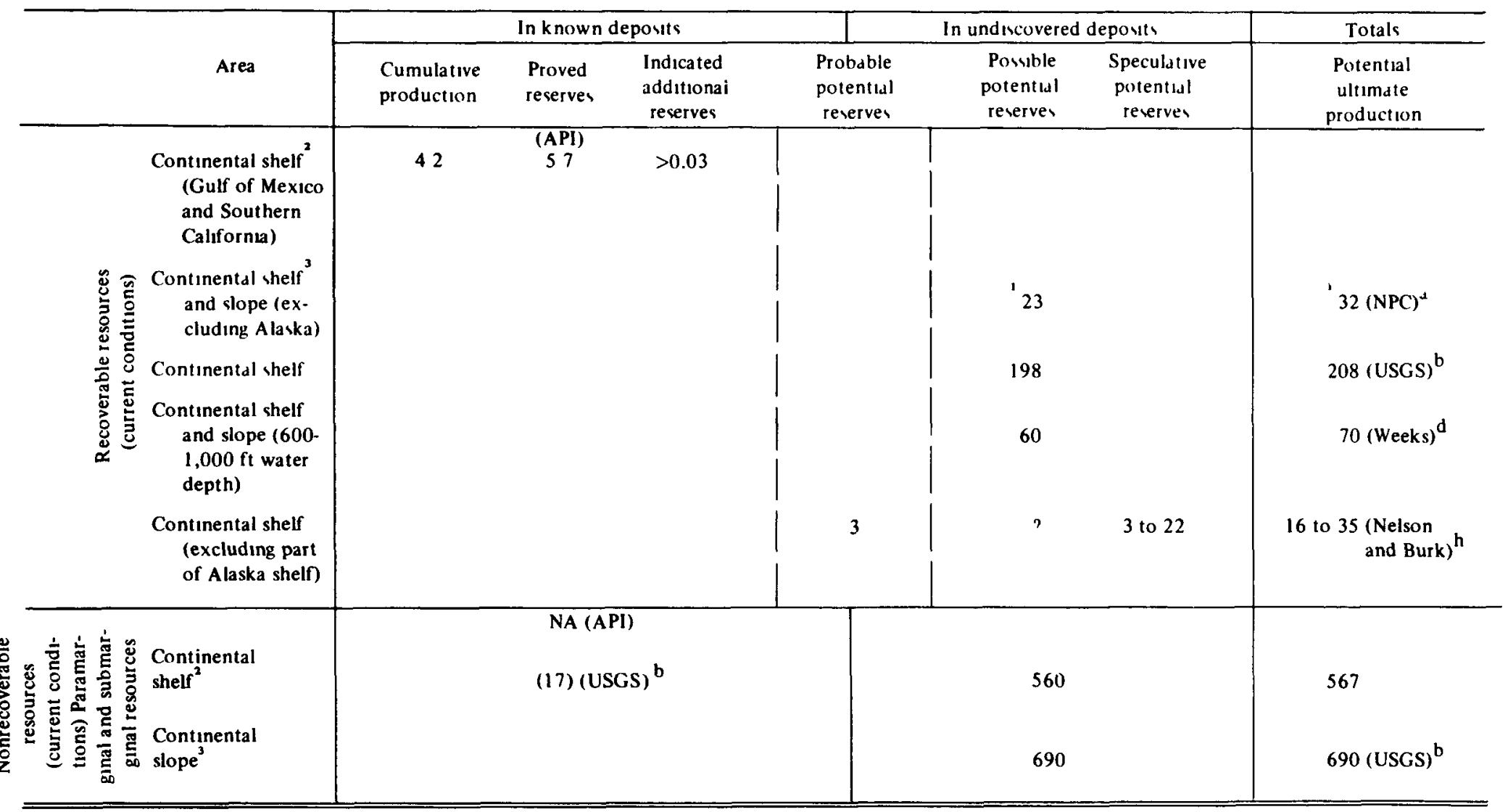

${ }_{2}^{1}$ Crude orl only

${ }_{3}^{2}$ Shelf, $0-200 \mathrm{~m}(0-656 \mathrm{ft})$ water depth

Slope, 200-2,500m $(656-8,250 \mathrm{ft})$

water depth.
Estımates of total petroleum liquids originally in place in United States contınental margins

\begin{tabular}{|c|c|c|c|c|}
\hline & $\mathrm{NPC}^{\mathrm{a}}$ & USGS $^{b}$ & Week $^{\mathrm{d}}$ & $\begin{array}{l}\text { Nelson and Burk } \\
46 \text { to } 100\end{array}$ \\
\hline $\begin{array}{l}\text { Shelf } \\
\text { Slope }\end{array}$ & 92 & $\begin{array}{l}775 \\
690\end{array}$ & 200 & 46 to 100 \\
\hline Total & $92^{\prime}$ & 1,465 & 200 & 46 to 100 \\
\hline
\end{tabular}

Figure 15.-Some estimates of United States original offshore resources of petroleum liquids (crude oil and natural-gas liquids in billions of barrels). Data to Dec. 31, 1970. The values reported in this figure are not rounded but are simply arithmetic calculations. The accuracy of the figures is largely unevaluated, and the number of significant figures is not indicated in the numbers. NA, not available. Lettered footnote symbols are explained in the section "Discussion of Individual Estimates." 


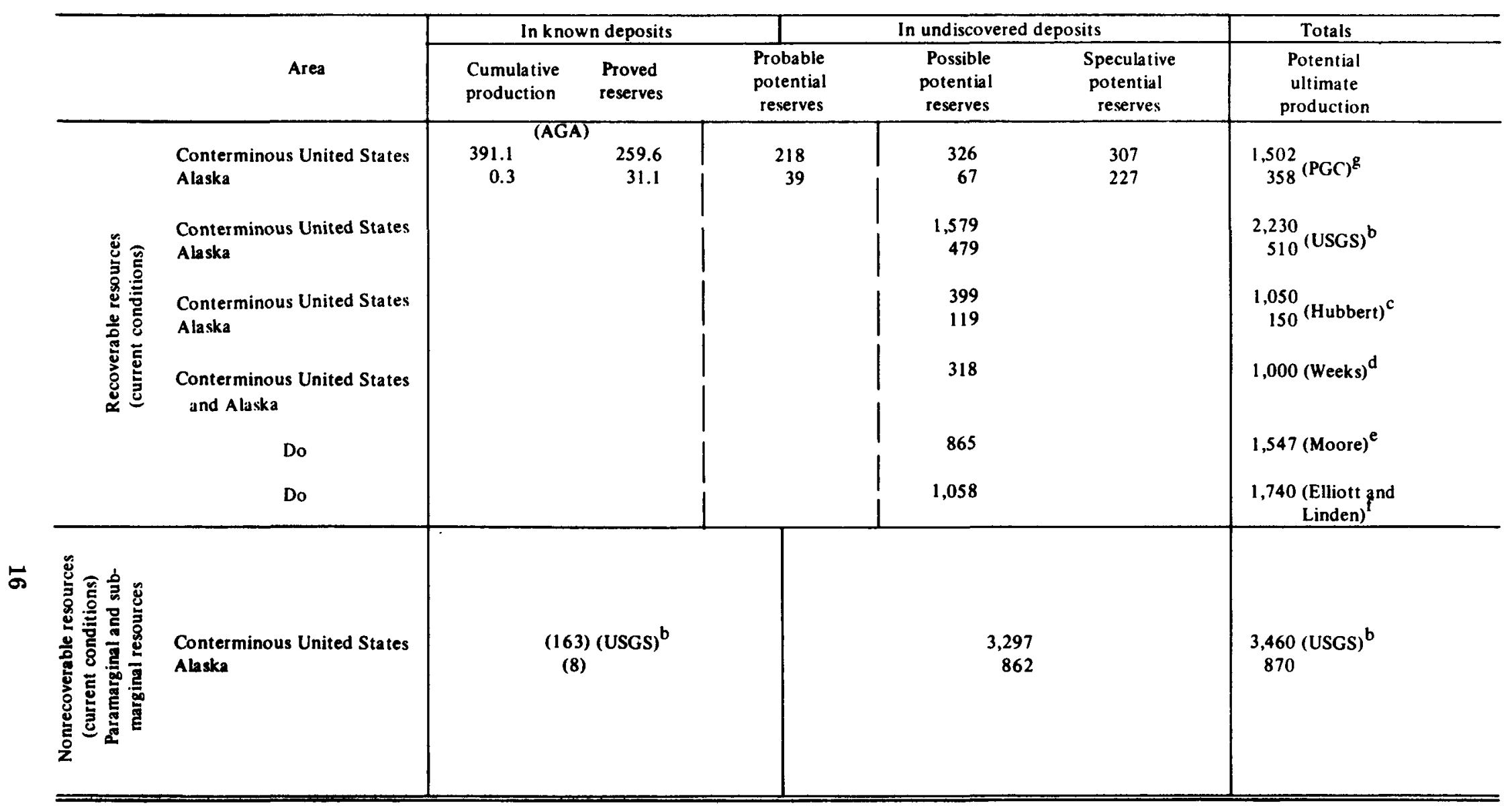

Estimates of total natural gas originally in place in the United States

$\begin{array}{lllllll} & \text { PGC }^{8} & \text { USGS }^{b} & \text { Hubbert }^{c} & \text { Weeks }^{d} & \text { Moore }^{\mathrm{e}} & \begin{array}{l}\text { Elliott and } \\ \text { Linden }^{\text {f }}\end{array} \\ \text { Conterminous United States } & 1,877 & \mathbf{5 , 6 9 0} & 1,312 & & & \\ \text { Alaska } & \frac{447}{1,324} & \frac{1,380}{7,070} & \frac{188}{1,500} & \overline{1,250} & \overline{1,934} & \overline{2,175}\end{array}$

Figure 16.-Some estimates of United States original resources of natural gas (in trillions of cubic feet, S.T.P. (standard temperature and pressure) ). Data to Dec. 31,1970 . The values reported in this figure are not rounded but are simply arithmetic calculations. The accuracy of the figures is largely unevaluated, and the number of significant figures is not indicated in the numbers. Lettered footnote symbols are explained in the section "Discussion of Individual Estimates." 


\begin{tabular}{|c|c|c|c|c|c|c|c|}
\hline & \multirow[b]{2}{*}{ Area } & \multicolumn{2}{|c|}{ In known deposits } & \multicolumn{3}{|c|}{ In undiscovered deposits } & \multirow{2}{*}{$\begin{array}{c}\text { Totals } \\
\text { Potential } \\
\text { ultimate } \\
\text { production }\end{array}$} \\
\hline & & $\begin{array}{l}\text { Cumulative } \\
\text { production }\end{array}$ & $\begin{array}{l}\text { Proved } \\
\text { reserves }\end{array}$ & $\begin{array}{l}\text { Probable } \\
\text { potentıal } \\
\text { reserves }\end{array}$ & $\begin{array}{l}\text { Possible } \\
\text { potential } \\
\text { reserves }\end{array}$ & $\begin{array}{c}\text { Speculative } \\
\text { potential } \\
\text { reserves }\end{array}$ & \\
\hline 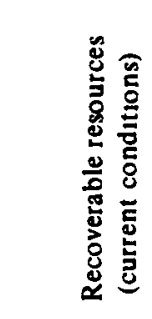 & $\begin{array}{l}\text { Conterminous United States } \\
\text { Alaska } \\
\text { Conterminous United States } \\
\text { Alaska } \\
\text { Conterminous United States } \\
\text { and Alaska }\end{array}$ & $\begin{array}{r}3742^{(A C} \\
3\end{array}$ & $\begin{array}{r}2205 \\
311\end{array}$ & 179 & $\begin{array}{r}227 \\
1,015 \\
199 \\
62\end{array}$ & 207 & $\begin{array}{l}\frac{1,208}{N A}(\text { PGC })^{g} \\
1,610, \quad b \\
231 \\
688(\text { Week },)^{d}\end{array}$ \\
\hline 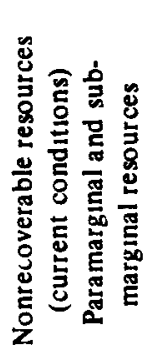 & $\begin{array}{l}\text { Conterminous United States } \\
\text { Alaska }\end{array}$ & (8) 1 & GS) & & $\begin{array}{r}1,491 \\
191\end{array}$ & & $\frac{1,640}{199}$ (USGS) $^{b}$ \\
\hline
\end{tabular}

Estimates of total natural gas originally in place in the land areas of the United Siates

$\begin{array}{lccc} & \text { PGC }^{g} & \text { USGS }^{b} & \text { Weeks }^{d} \\ \text { Conterminou, United Stute, } & 1,510 & 3,250 & 860 \\ \text { Alushd } & & \frac{430}{3,680} & \overline{860}\end{array}$

Figure 17.-Some estımates of United States on iginal onshore resouıces of natural gas (in tillions of cubic feet, $S T P$ ) Data to Dec. 31, 1970 The values reported in this figure are not rounded but are simply arithmetic calculations The accuracy of the figures is largely unevaluated, and the number of significant figures is not indicated in the numbers NA. not avalable Lettered footnote symbols are explained in the section "Discusion of Individual Estimates." 


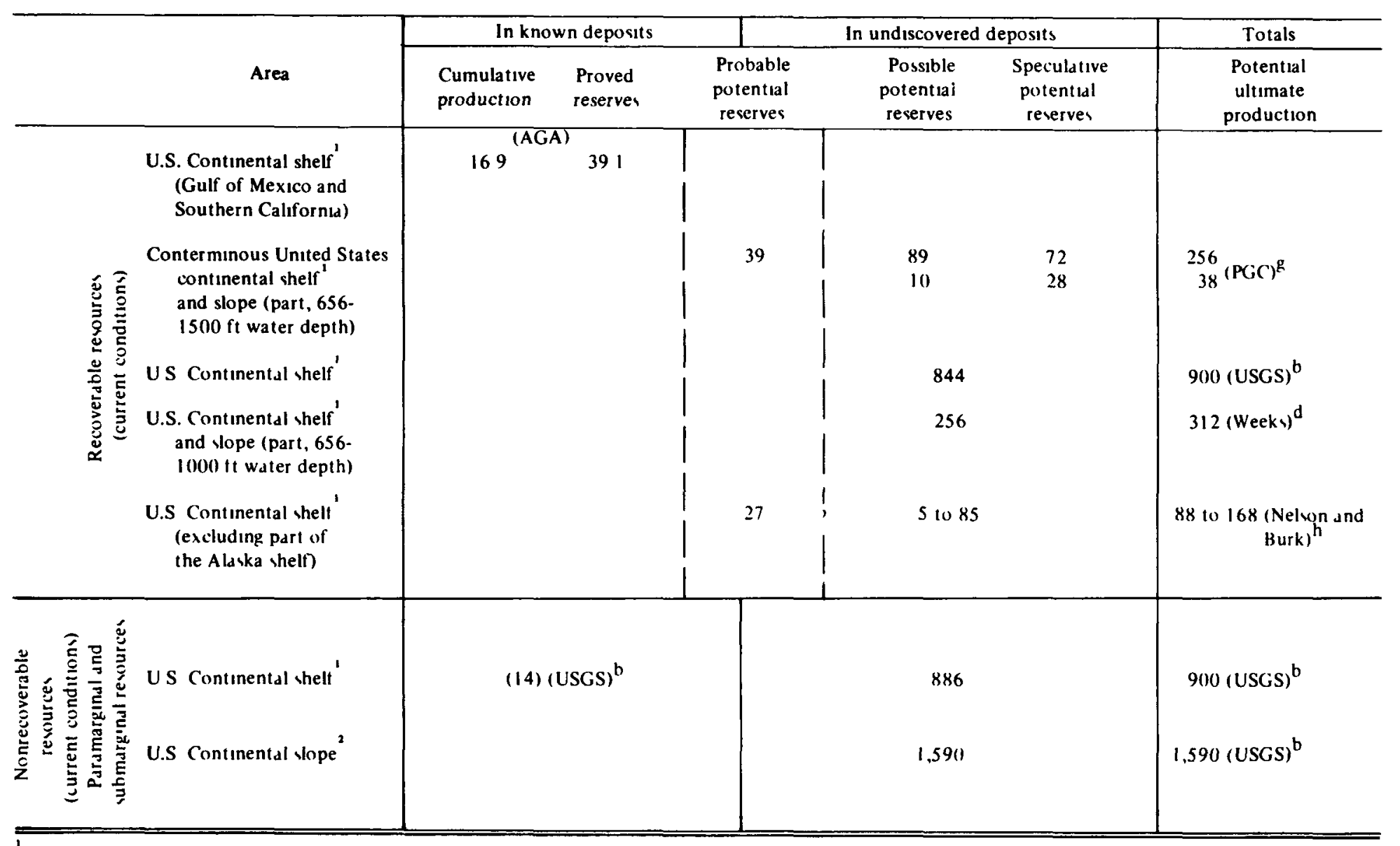

Shelf, $0-200 \mathrm{~m}(0-656 \mathrm{ft})$

2 water depth

Slope, $200-2,500 \mathrm{~m}(656$ -

$8,250 \mathrm{ft}$ ) water depth

Estimates of total natural gas onginally in place in United States continental margins

$\begin{array}{lcccc} & \text { PGC }^{\text {g }} & \text { USGS }^{b} & \text { Week }^{d} & \text { Nelson And Burk } \\ \text { Shelt } & 320 & 1800 & 390 & 110-210 \\ \text { Slope } & \frac{47}{367} & \frac{1,590}{3,390} & \overline{390} & \overline{110-210}\end{array}$

FIGURE 18.-Some estimates of United States original off shore resources of natural gas (in trillons of cubic feet, S.T.P.). Data to Dec. 31, 1970. The values reported in this figure are not rounded but are simp ithmetic calculations. The accuracy of the figures is largely unevaluated, and the number of significant figures is not indicated in the numbers. Lettered footnote symbols are explained in the section "Discussion of Individual Estimates." 


\section{UNDISCOVERED DEPOSITS}

The terms probable-, possible-, and speculative-potential reserves are defined by the Potential Gas Committee (Colorado School Mines Found., Potential Gas Ager.y, 1971, p. 11) to categorize estimates of undise red but recoverable, if found, resources of natural gas by degree of reliability of the estimate. Reliability decreases from left to right, probable being the most reliable and speculative the least. The probable category includes, however, some known resources, in the sense of having been discovered but not completely developed, and some unknown resources, so that this category brackets the boundary between the known and the unknown. This terminology was adopted by the National Petroleum Council (NPC) (Miller and others, 1970) for its report on future petroleum provinces of the United States, but estimates were reported as probable-possible combined and speculative.

Estimates of potential reserves of NGL are not made by the PGC. The NPC did estimate potential $N G L$ reserves but reported them in a lump sum for the United States and not in the aforementioned categories.

The term potential ultimate production under the total columns of figures 13-18 is one used here for convenience by the USGS and is self explanatory. It is the sum of estimates of cumulative production, known recoverable, and undiscovered recoverable resources of petroleum.

The term current conditions refers to the current well-head price structure for oil and gas and current recovery factors, or, more succinctly, to current economics and technology.

\section{TOTAL RESOURCES IN PLACE}

The estimates of total petroleum liquids, or natural gas, originally in place in the United States (lower part of figs. 13-18) are estimates of total original quantities of petroleum in discrete deposits in the earth and consist of the sum of the quantities for a given estimate in each of the four categories of resources, that is, known recoverable + known para- and submarginal + undiscovered recoverable + undiscovered para- and submarginal. In most estimates, the quantities of undiscovered para- and submarginal resources had to be calculated from the author's reported estimate of ultimate production by applying an appropriate recovery factor (80 percent for gas and NGL, 35 percent for oil).

\section{INDIVIDUAL ESTIMATES}

The API and the AGA have provided the only estimates of known resources of oil and gas. Therefore, their data alone were used to fill in those categories except for known paraand submarginal resources of natural gas, which were estimated by the USGS.

Estimates of undiscovered resources made by the NPC and PGC for liquids and gas, respectively, are listed first in figures 13-18 because these agencies were most responsible for the development and use of the terminology. Other estimates are listed in order of the relative amount of detail reported. For total United States and onshore United States (figs. 13, 14, $16,17)$, it was felt that the conterminous States and Alaska should be reported separately insofar as possible because of the distance and transportation difficulties associated with Alaska. For the United States offshore areas (figs. 15 and 18), it was felt that the most important aspect is water depth; division of the area into shelf and slope has become customary (by convention, the shelf is the area between 0 and $200 \mathrm{~m}$ ( 0 and $656 \mathrm{ft}$ ) and the slope is the area between 200 and $2,500 \mathrm{~m}$ (656 and 8,250 ft)).

\section{METHODOLOGY}

In general, two basic methods, geologic and mathematical were used by the authors reported here; in detail, however, each author used a method that was somewhat different from the others.

\section{Geologic Methods}

The geologic method was used by the NPC, PGC, USGS, and L. G. Weeks, and apparently by T. W. Nelson and C. A. Burk; the mathematical method was used by M. K. Hubbert, C. L. Moore, and M. A. Elliott and H. R. Linden. Both basic methods employ more or less 
of the statistical records of past oil and gas explorations and production; the mathematical method is based entirely on those statistics.

Comparison is difficult between the estimates made by each basic method but, roughly, the most similar in terms of method are the estimates made by the NPC, PGC, and L. W Weeks. Possibly Nelson and Burk's work also belongs in this group, but they also use the mathematical methods.

In terms of area and depth (rock volume) of favorable strata, the estimates of the USGS were applied to the largest potential area. The PGC comes next closest in area; however, as it includes potential rocks to drilling depths of 30,000 feet, whereas the USGS estimates include potential rocks only to drilling depths of 20,000 feet, the rock volume used by the PGC might be as large as that used by the USGS.

\section{Mathematical Methods}

Theoretically, at least, all the mathematical estimates cover the same area (and volume), which should be the total of all the potential oil- and gas-producing rocks in the United States. This is so because the mathematical methods supposedly take into account all evolutionary trends in the exploration and production of oil and gas, and one very definite trend is toward the deeper rocks and more remote areas believed to have oil and gas potential. Consequently, the areas (volumes) taken into account should include at least as much territory as the USGS estimates do. (Practically speaking, they probably do not, but this subject is too complicated for these notes.)

Other authors have included more or less of the potential oil- and gas-producing areas, for various reasons to be discussed later.

Most estimates of resources of natural gas (and NGL) are arrived at by applying a gasoil ratio to estimated oil resources, This method, called the gas-oil ratio method, although less satisfactory, was used by the USGS and M. K. Hubbert. L. C. Weeks and Nelson and Burk have provided little information on their methodology, but they may have used some form of this technique.

The ratio of NGL to gas is applied to the estimate of gas resources to obtain the esti- mate of resources of NGL. Estimates of potential future reserves by other than the NPC and $P G C$ are in figures 13-18, centered under the undiscovered deposits column below the possible potential reserves column only for convenience. The estimates actually range from the probable to the speculative categories but cannot be broken down in that detail because of lack of information.

\section{DISCUSSION OF INDIVIDUAL ESTIMATES}

Figures 13-18 provide a tabular comparison of the various estimates according to the category of the resource being estimated. In the discussion that follows, the letter designations preceding each section serve as foctnotes to these figures.

\section{(a) National Petroleum Council}

The data used were taken from tau.. 22 , p. 104 , and several paragraphs of the report by Miller and others (1970). Their table 22 was based on a recovery factor for crude oil of $\mathbf{3 0}$ percent.

The original oil-in-place was estimated by NPC for each of 11 regions, in the three categories of probable, possible, and speculative, but the estimates for the probable and possible categories were reported as one figure. Ultimate recovery estimates were also made by the NPC using recovery factors of 42 percent and 60 percent, but they have not been included in figures 13-18.

A flat estimate of 49 billion barrels of ultimately recoverable NGL was reported in table 25 , p. 108, of the NPC report (Miller and others, 1970) without any details as to how this quantity should be assigned to the various regions. Therefore, it is reported as a single number in figure 13. The quantity of original NGL-in-place reported under the NPC at the bottom of figure 13 was calculated by the USGS on the basis of an 80 percent recovery factor.

Future potential gas reserves were also reported in the NPC publication, but as these had been received from the $P G C$, they are reported in figure 16 with PGC as the source.

A variety of geologic methods were used in preparing the NPC report. The methods in- 
clude extrapolation and interpolation along trends, comparison of similar areas and strata, evaluation of structures determined by geophysical prospecting, evaluation of the undrilled parts of known fields and pools, and assignment of average oil incidence to rock volumes. The results, though conservative, are probably the most detailed estimate of potential crude-oil reserves that has been made for the United States to date.

Some oil in the probable-possible category can be considered to have been already discovered but not cited as proved reserve at the time the NPC report was prepared. This is oil in undeveloped parts of fields and pools that have been "discovered" but not drilled out. There is no way to tell, from the report, how much this might be, but roughly it might be assumed to be an amount nearly equal to the proved reserves reported by the API.

The NPC report does not cover all potentially favorable areas. Those left out are onshore and offshore areas of Washington and Oregon; parts of North Dakota, South Dakota, Michigan, Montana, and the Great Basin area; the offshore areas of Alaska, except for parts of Cook Inlet and Bristol Bay; and the offshore areas of California north of the Santa Barbara Channel.

\section{(b) The U.S. Geological Survey}

The crude oil estimates made by the USGS have been prepared by a method developed by A. D. Zapp and T. A. Hendricks (Hendricks, 1965). The method is basically geologic and involves applying the historical results of past exploratory drilling to unexplored rocks on an equal basis for all of the favorable strata of the United States, including Alaska and the continental margins to a water depth of 2,500 $\mathrm{m}(8,250 \mathrm{ft})$. This is, therefore, the only geology-based estimating method that is entirely consistent. This method is not necessarily good, however, in estimating potential resources because not all regions are alike in their geology and petroleum potential. On the other hand, if the method is applied to large enough areas, it is felt that errors will average out, and at least a valuable first approximation will result.
The resulting estimate is of total original oil-in-place from which the various other categories can be calculated by applying suitable finding and recovery factors. It is assumed that five-eighths of the oil-in-place could be found with current exploration technology and that 40 percent of the oil found could be produced; this defines the proportion of the original oil-in-place that would be recoverable. (Forty percent was used to take into account projected near-term increases in crude-oil recovery.) Potential resources of natural gas and NGL are determined by applying a gas-oil ratio to estimated quantities of oil and a NGLgas ratio to the resultant gas estimate. The application of gas-oil and NGL-gas ratios differs from the usual in that the ratios used are for gas-in-place to oil-in-place, whereas the usual method is to use only ratios of proved reserves of gas to oil or ratios of cumulative production of gas to oil. The result is original gas and NGL-in-place to which a finding factor of five-eighths is applied, as for oil. In this case, however, a recovery factor of 80 percent is used to reflect the average experience in gas and NGL production.

Para- and submarginal resources are those either not recoverable, or not found and not recoverable because of size and location or recovery technology and low price. Future advances in recovery technology or increases in price could make some of these known and $u n$ discovered para- and submarginal resources recoverable.

Resource estimates have been prepared by the USGS for the conterminous United States and Alaska and for two zones of the continental margins, from 0 to $200 \mathrm{~m}$ (shelf) and 200 to $2,500 \mathrm{~m}$ (slope). The resources estimated for the continental slope are believed to be generally out of reach both technologically and economically at this time and therefore have been placed entirely in the undiscovered para- and submarginal categories.

\section{(c) M. K. HUBBerT}

Hubbert prepared his estimate of ultimate production of crude oil mathematically from historical data on reserve additions for the conterminous United States and its contiguous 
shelves. Ultimate gas production was calculated from a gas-oil ratio and NGL from a NGL-gas ratio. For Alaska, Hubbert used geologic analogy to estimate ultimate crude-oil production and gas-oil, NGL-gas ratios for the ultimate production of gas and NGL. The estimate of original resources in place shown on figures 14, 15, 17 and 18 were calculated by the USGS. There is no way to subdivide Hubbert's estimates for the land and continental margins.

\section{(d) L. G. WeEKS}

Weeks $(1958,1959)$ prepared his estimate of ultimate production by geologic methods but never fully described the methods nor whether or not his estimate of ultimate gas production was based on a gas-oil ratio.

He made an estimate of ultimate production for the conterminous United States and Alaska combined land and offshore areas, but areas such as the Atlantic Coast and offshore, where there had been very little or no petroleum experience, were not included, and the offshore areas were carried only to a water depth of 1,000 feet (1,000 feet is only slightly deeper than the seaward edge of the continental shelf).

\section{(e) C. L. MOORE}

Moore based his resource estimates on mathematical calculations of the historic patterns of discovery and recovery of each commodity separately. Consequently, there are independent estimates for crude oil, natural gas, and NGL. For oil, Moore calculated total original oil-in-place and applied a calculated ultimate recovery factor to that to get ultimate oil production; this was not done for either gas or NGL, however, so the USGS calculated original in-place values for them.

The quantity for ultimate crude-oil production reported by Moore is based on a much higher recovery factor than any of the other estimates used. There was no way, however, to back up an ultimate production at either 30 , 35 , or 40 percent, so Moore's estimate was reported just as given by him. By Moore's calculation, much future oil production will have to come from both the known and unknown para- and submarginal resource category, so the numbers reported cannot be broken down into known and undiscovered para- and submarginal categories with any meaning.

(f) M. A. Elliott and H. R. Linden

Elliott and Linden used a mathematical method based on the historical statistics of cumulative production and reserve additions to arrive at independent estimates of the ultimate production (called ultimately economically recoverable by them) both of crude oil and natural gas. They did not separate these estimates into regional subdivisions nor did they estimate NGL resources. Estimates of total original resources in place were calculated by the USGS.

\section{(g) Potential Gas Committee}

The estimates of potential supply of natural gas in the United States reported by the PGC (Colorado School of Mines Foundation, Inc., Potential Gas Agency) are made by a variety of geologic methods (these were outlined above under the NPC). These estimates are made for the largest possible area of favorable ground after those of the USGS and are made independently of a gas-oil ratio.

Gas resources are reported by three categories of reliability and for 12 areas of the United States. Within the 12 areas, except for Alaska, resources are reported by two drilling depths on land and by two water depth zones offshore. The drilling zones are 0-15,000 feet and 15,000-30,000 feet, and the offshore water depth zones are 0-600 feet and 600-1,500 feet. Estimates for Alaska are not further broken down by depths or areas.

Part of the quantities estimated in the probable potential reserve category can be considered as discovered for the reasons discussed above under the NPC.

The PGC does not estimate total original gas-in-place, so the estimate shown was prepared by the USGS.

(h) T. W. Nelson and C. A. Burk

Nelson and Burk's estimates were only for "undeveloped and unfound" petroleum reserves of the United States continental mar- 
gins. Presumably these estimates were prepared by geologic methods, but this is not explained by the authors. The estimates do not include all of the Alaska shelves.

The estimated quantities were reported as prospective and speculative and include petroleum liquids and natural gas. The prospective quantities were equated in figure 18 with the probable potential category but with a question as to how much might actually fall under the possible potential category. The speculative quantities are given as a range by the authors and were placed herein in figure 18 under the possible and speculative categories. Potential ultimate production and original resources-in-place were calculated by the USGS.

From the tone of Nelson and Burk's report, it is assumed that they were dealing only with the continental shelf, or the zone 0-200 m deep.

\section{URANIUM RESOURCES}

The resources are presented in two diagrams. The first is for conventional deposits where uranium is the major product of value (fig. 19). The second is for deposits of other materials from which uranium may be recovered as a byproduct (fig. 20). Short tons of uranium oxide $\left(\mathrm{U}_{3} \mathrm{O}_{8}\right)$ in the ground are the units for estimation of uranium resources.

All the identified recoverable resources are in conventional deposits. The estimate, 250,000 tons, is rounded from the AEC estimate of 246,000 tons as of January 1971 (U.S. Atomic Energy Comm., 1971), based on a cutoff price of $\$ 8$ per pound of $\mathrm{U}_{3} \mathrm{O}_{8}$. Mining loss is not significant. The identified recoverable resources estimate has an accuracy of about plus or minus 20 percent.

The identified submarginal resource is estimated to a cutoff at $\$ 15$ per pound of $\mathrm{U}_{3} \mathrm{O}_{8}$. About a quarter of the submarginal material could be recovered at $\$ 10$ per pound of $\mathrm{U}_{3} \mathrm{O}_{8}$. The submarginal resource is less than the recoverable resource because the halo of lower grade material surrounding the ore is generally small.

Conventional undiscovered resources in known uranium districts are estimated to be twice the amount of the identified resource. This estimate is based on the productivity of favorable rocks along their outcrop, measured in tons per linear mile of exposure. This measure is then extrapolated to the third dimen-

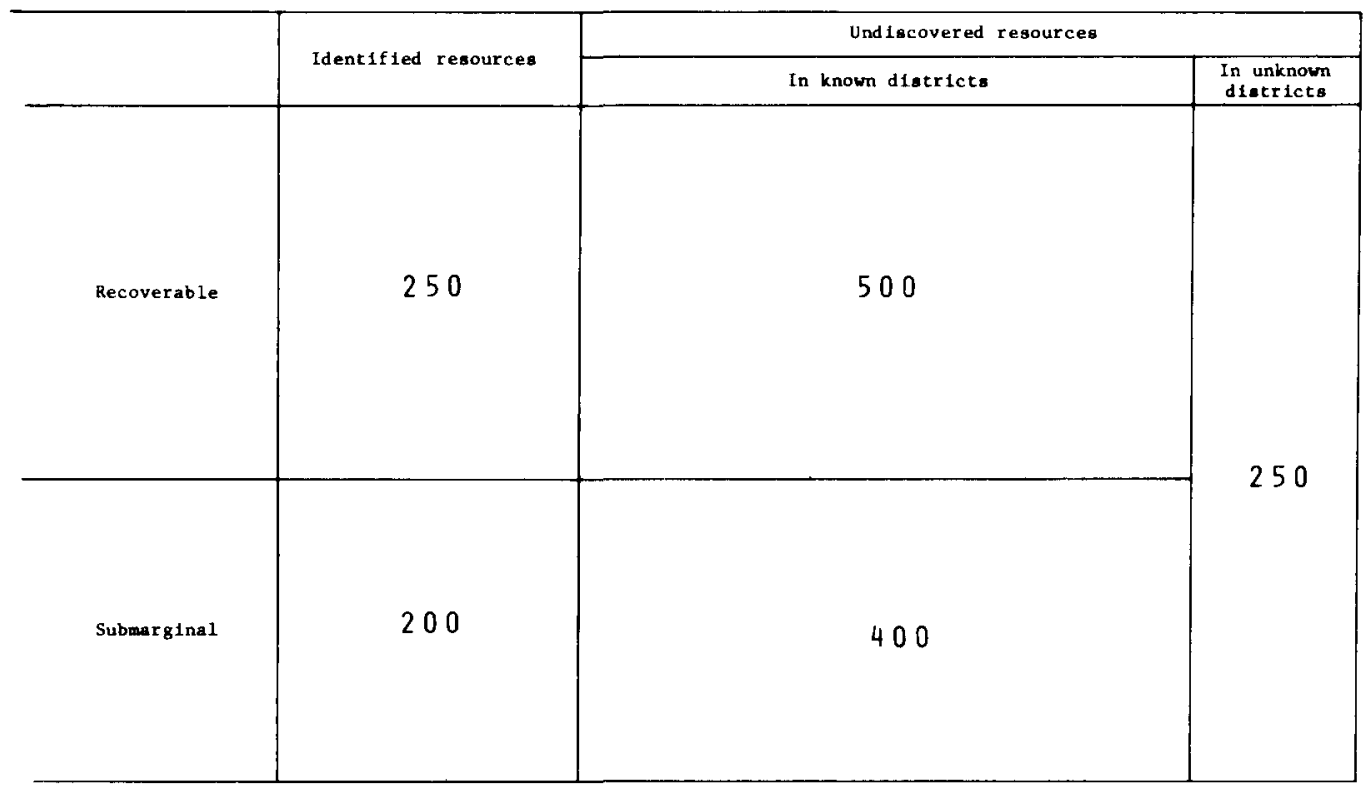

Figure 19.-Scaled diagram of uranium resources of conventional deposits in the United States (thousands of short tons of $\mathrm{U}_{3} \mathrm{O}_{8}$ ). Reliability of estimates decreases downward and to the right. Compiled by A. P. Butler, Jr., and W. I. Finch, February 1972. 


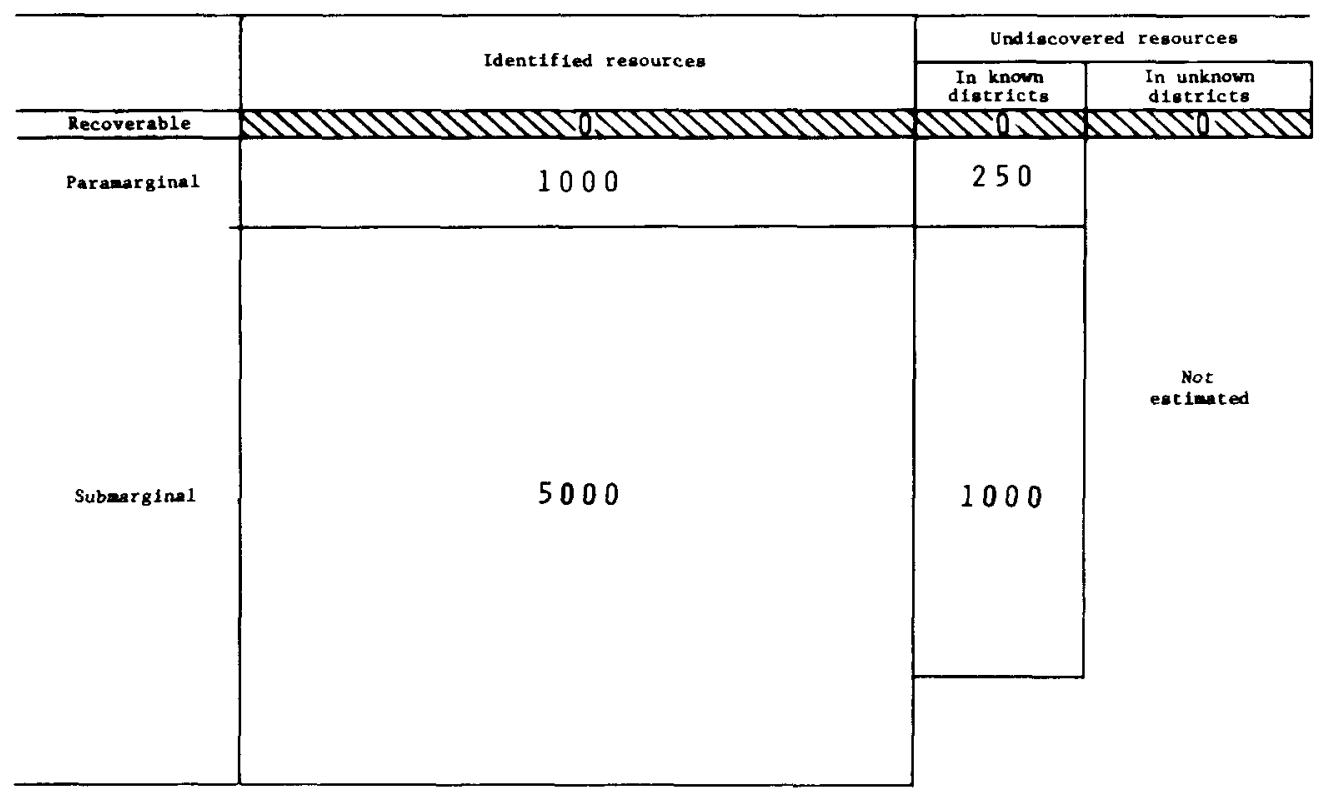

FIGURE 20.-Scaled diagram of uranium resources in phosphate rock in the United States (thousands of short tons of $\mathrm{U}_{3} \mathrm{O}_{8}$ ). Reliability of estimates decreases downward and to the right. Compiled by A. P. Butler, Jr., and W. I. Finch.

sion, down the dip of the favorable rocks beneath the basin, to obtain an approximation of the total amount of uranium that may be present.

Most of the sedimentary basins favorable for the accumulation of conventional uranium deposits have been tested, so it is not likely that the resource in undiscovered deposits in undiscovered districts will be large. This last figure is estimated to be about the same as the identified resource. The estimate of undiscovered resources is thought to be within about a factor of 2 of the correct value. The total resource base is estimated to be about $1,600,000$ tons.

Byproduct uranium resources are dominated by the potential resource in phosphate rock. At present, all this resource is submarginal. Two grades of material are considered in the diagram. The paramarginal resource is rock containing at least 31 percent $\mathrm{P}_{2} \mathrm{O}_{5}$ and approximately 0.012 percent $\mathrm{U}_{3} \mathrm{O}_{8}$. Recovery as a byproduct would be feasible at $\$ 10$ per pound of $\mathrm{U}_{3} \mathrm{O}_{8}$. The submarginal resource is in rock containing 18-30 percent $\mathrm{P}_{2} \mathrm{O}_{5}$ and 0.006-0.012 percent $\mathrm{U}_{3} \mathrm{O}_{8}$. Recovery as a byproduct would be feasible at about $\$ 20$ per pound of $\mathrm{U}_{3} \mathrm{O}_{8}$. The distribution of this resource into identified and undiscovered categories reflects our knowledge of phosphate resources; that is, about five-sixths of the anticipated resource is identified. As a potential resource for uranium, this part of the resource base diminishes with time as the rock is mined for its phosphate content.

The principal references are U.S. Atomic Energy Commission (1971) and Bieniewski, Persse, and Brauch (1971).

\section{GEOTHERMAL RESOURCES}

The units of geothermal energy used in figure 21 are calories of heat in the ground. These are calories in excess of normal surface heat-taken to be about $15^{\circ} \mathrm{C}$.

The identified recoverable resources of geothermal energy are such a small part of the total energy resource that subdivision of the remainder of the resources base is unrealistic at this time. The Geysers, Calif., is the only operating geothermal system in the United States and provides the only domestic base for estimation of the recoverable resource. Measured and indicated resources at The Geysers are estimated to be $2 \times 10^{18}$ and $3 \times 10^{18}$ calories, respectively, in the ground. (Gram-calories, equivalent to $4 \times 10^{-3} \mathrm{Btu}$, are used throughout this discussion.) With current technology, only 


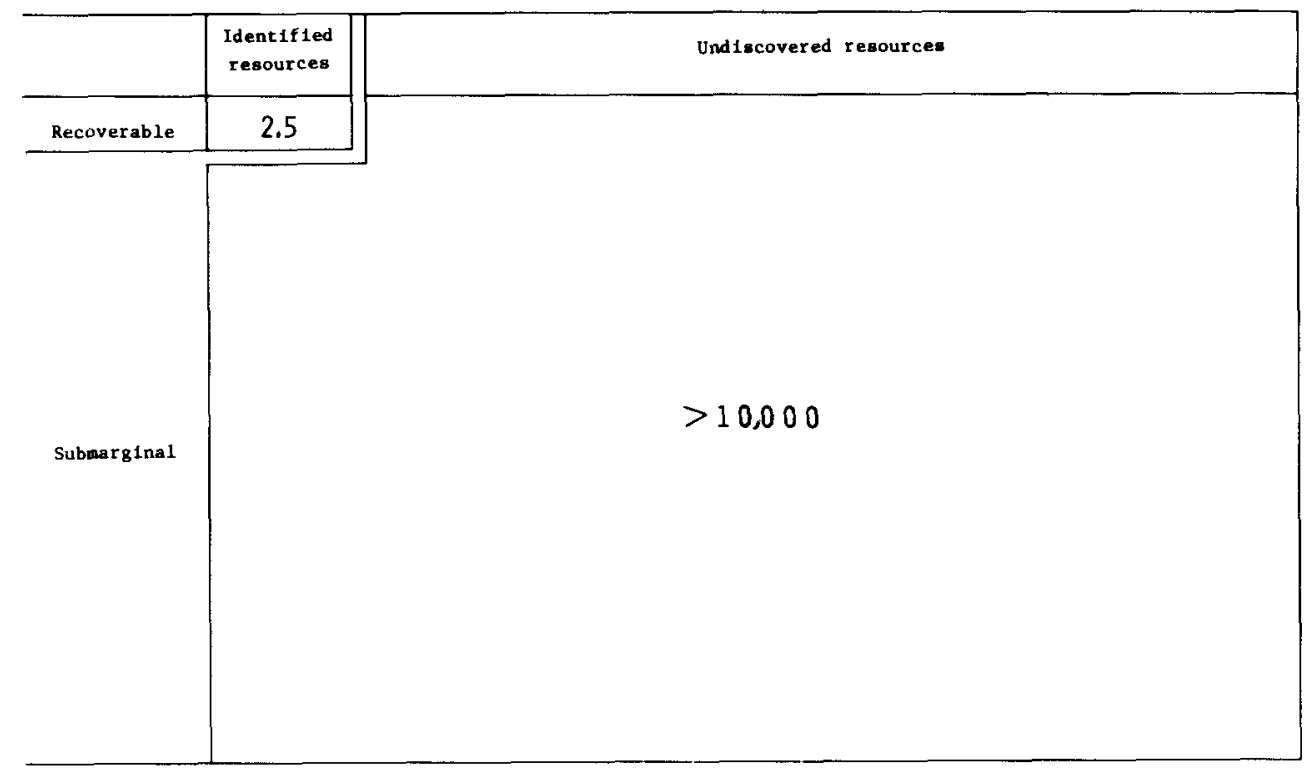

FIGURE 21.-Diagram of geothermal resources in the United States (10 calories). Reliability of estimates decreases downward and to the right. Compiled by L. J. P. Muffler and D. E. White, February 1972.

about 15 percent of this energy is delivered to the well head, so the actual recoverable resource in the proved and probable category is about $0.8 \times 10^{18}$ calories. An additional $5 \times 10^{18}$ calories in the ground can be inferred for The Geysers area, and at least another $5 \times 10^{18}$ calories in the ground in other parts of the country are reasonably inferred from geologic knowledge and from limited exploration drilling. The inferred reserve for the United States is, therefore, at least $10 \times 10^{18}$ calories in the ground, or about $1.5 \times 10^{18}$ calories recoverable with current technology. The total identified recoverable resource for the United States is, therefore, about $2.5 \times 10^{18}$ calories. Geothermal energy in the National Parks System is excluded from the recoverable estimate.

The estimate of undiscovered resources shown in the figure as $10,000 \times 10^{18}$ calories is based on White's (1965) estimate of $10^{22}$ calories in the ground in all hydrothermal systems of the world. The United States resource is about 10 percent of this, and the estimate is increased by a factor of 10 to include abnormally hot, or possibly molten, rocks of low permeability, and deep sedimentary basins of near-normal conductive gradient. The estimate includes resources only to a depth of $10 \mathrm{~km}$ and is conservative.
The principal references are White (1965) and Muffler and White (1972).

\section{OIL-SHALE RESOURCES}

Resources of oil shale (fig. 22) are considered submarginal, although the best grade and most accessible deposits would yield oil at a moderate increase in price of oil into the range $\$ 4$ to $\$ 5$ per barrel, according to a recent study (Natl. Petroleum Council, 1971).

The units shown are barrels (42 gallons) of oil that could be obtained from the shale if it were treated in a retort to convert part of the solid organic matter to oil. Hydrogenation of the oil would be required to produce a marketable high-quality synthetic crude.

The identified resources include deposits that have been mapped and sampled sufficiently to determine size and oil-yielding potential with moderate accuracy, certainly within plus or minus 50 percent.

The identfiied paramarginal resources have recently been estimated by the NPC to contain about 80 billion barrels of oil recoverable at \$4-\$5 per barrel. These deposits include the more accessible oil shale in Colorado and Utah, yielding 30 gallons or more oil per ton. An additional 520 billion barrels has been identi- 


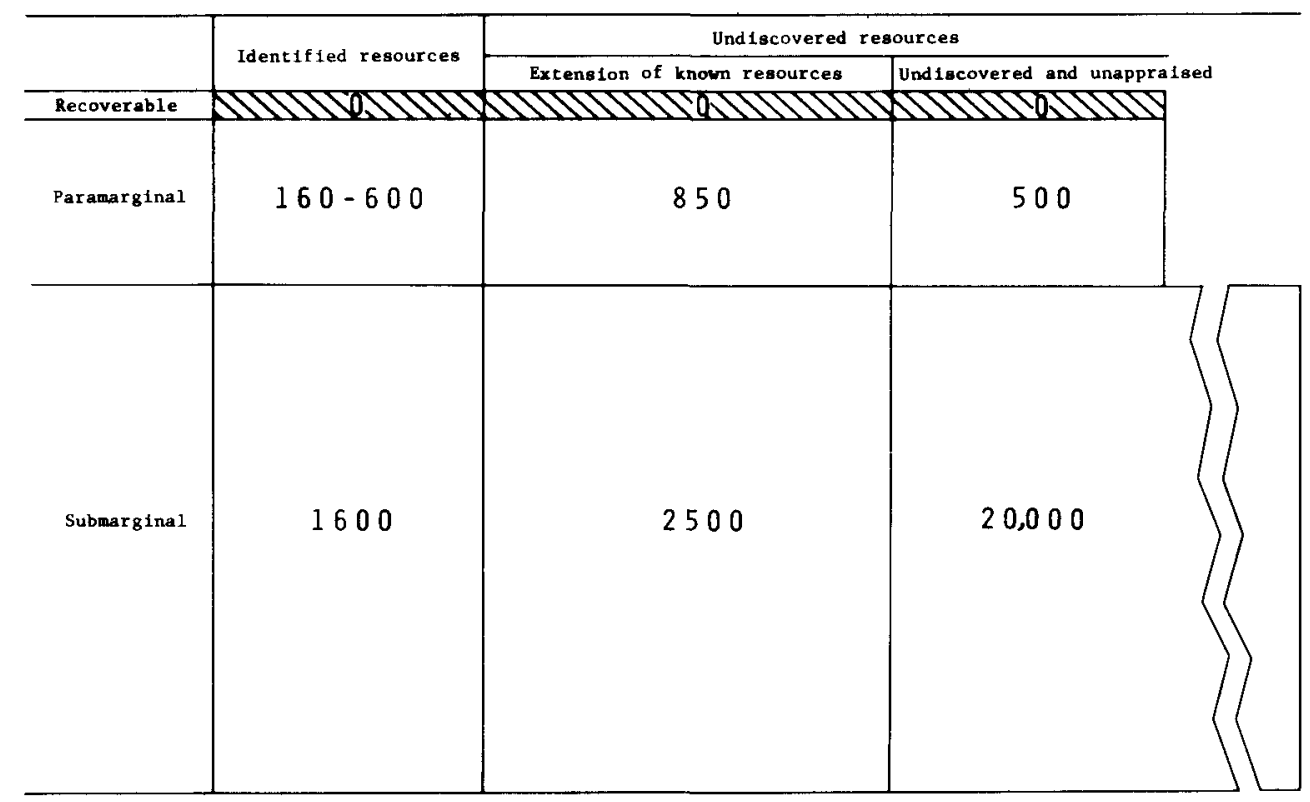

FIGURE 22.-Scaled diagram of oil-shale resources in the United States (billions of barrels). Reliability of estimates decreases downward and to the right. Compiled by D. C. Duncan, February 1972.

fied in less accessible shale of similar grade. Undiscovered resources of this quality within 3,000 feet of the surface are included in the paramarginal category.

The undiscovered resources include: (1) possible extensions of identified deposits, in areas where they are inadequately sampled for reliable resource estimation; (2) deposits that have not been sampled sufficiently to make reliable estimates of oil content; and (3) a statistical estimate of shale containing 10 percent or more organic matter capable of yielding 10 gallons or more oil per ton of shale in sedimentary rocks of the land areas of the United States. Deposits extending to a maximum depth of 20,000 feet are included. The twofold subdivision of the undiscovered resources on the diagram falls between category 1 and categories 2 and 3 .

The oil-shale resource estimates were derived mainly from Duncan and Swanson (1965).

\section{REFERENCES CITED}

American Gas Association, American Petroleum Institute, and Canadian Petroleum Association, 1971. Reserves of crude oil, natural gas liquids, and natural gas in the United States and Canada as of December 31, 1970: Am. Gas Assoc., Am. Petroleum Inst., and Canadian Petroleum Assoc., 256 p. (v. 25 of an annual publication).

Averitt, Paul, 1969, Coal resources of the United States, January 1, 1967: U.S. Geol. Survey Bull. $1275,116 \mathrm{p}$.

Bieniewski, C. L., Persse, F. H., and Brauch, E. F., 1971, Availability of uranium at various prices from resources in the United States: U.S. Bur. Mines Inf. Circ. 8501, 91 p.

Colorado School of Mines, Golden, Foundation, Inc., Potential Gas Agency, 1971, Potential supply of natural gas in the United States (as of December 31, 1970) : Golden, Colo., 41 p.

DeCarlo, J. A., Sheridan, E. T., and Murphy, Z. E., 1966, Sulfur content of United States coals: U.S. Bur. Mines Inf. Circ. 8312, 44 p.

Duncan, D. C., and Swanson, V. E., 1965, Organic-rich shale of the United States and world land areas: U.S. Geol. Survey Cir. 523, 30 p.

Elliott, M. A., and Linden, H. R., 1968, A new analysis of U.S. natural gas supplies: Jour. Petroleum Technology, v. 20, p. 135-141.

Hendricks, T. A., 1965, Resources of oil, gas, and natural-gas liquids in the United States and the world: U.S. Geol. Survey Cir. 522, 20 p.

Hubbert, M. K., 1969, Energy resources, in Resources and man: Natl. Acad. Sci.-Natl. Research Council, Comm. on Resources and Man, p. 157-242.

McKelvey, V. E., and others, 1969, Potential mineral resources of the United States outer continental 
shelf, in Public Land Law Review Commission Study of outer continental shelf lands of the United States, Volume IV (Appendices): available from: Natl. Tech. Inf. Service, U.S. Dept. of Commerce, Springfield, Va. 22151.

1972, Mineral resource estimates and public policy: Am. Scientist, v. 60 , no. 1, p. 32-40.

Miller, O. N., and others, 1970, Future petroleum provinces of the United States: Washington, D.C., Natl. Petroleum Council, 138 p.

Moore, C. L., 1970, Analysis and projection of historic patterns of U.S. crude oil and natural gas, in Miller, O. N., and others, Future petroleum provinces of the United States: Washington, D.C., National Petroleum Council, p. 133-138.

Muffler, L. J. P., and White, D. E., 1972, Geothermal energy: The Science Teacher, v. 39 , no. 3, p. 40-43.

National Petroleum Council, Committee on U.S. Energy Outlook, 1971, U.S. energy outlook: Washington, D.C., v. 1, 75 p., v. 2, 195 p.
Nelson, T. W., and Burk, C. A., 1966, Petroleum resources of the continental margins of the United States, in Exploiting the Ocean-MTS Conf. and Exhibit, 2d Ann., 1966, Trans.: Washington, D.C., Marine Technology Soc., p. 116-133.

U.S. Atomic Energy Commission, 1971, Statistical data of the uranium industry, Jan. 1, 1971: Grand Junction, Colo., 54 p.

U.S. Bureau of Mines, 1971, United States coal resources and production-an interim report, June 1971: Washington, D.C., 47 p.

U.S. Dept. Interior, 1972, United States energy, a summary review: Washington, D.C., 72 p.

Weeks, L. G., 1958, Fuel reserves of the future: Am. Assoc. Petroleum Geologists Bull., v. 42, no. 2, p. 431-441.

- 1959, Where will energy come from in 2059: The Petroleum Engineer, v. 31, p. A-25.

White, D. E., 1965, Geothermal energy: U.S. Geol. Survey Circ. 519, 17 p. 
